\title{
Kidney Mass and Relative Medullary Thickness of Rodents in Relation to Habitat, Body Size, and Phylogeny
}

\author{
Mohammed A. Al-kahtani ${ }^{1, \star}$ \\ Carlos Zuleta ${ }^{2}$ \\ Enrique Caviedes-Vidal ${ }^{3}$ \\ Theodore Garland, Jr., ${ }^{4}$
}

${ }^{1}$ Department of Zoology, University of Wisconsin, Madison, Wisconsin 53706; ${ }^{2}$ Departamento de Biologia, Universidad de La Serena, Casilla 599, La Serena, Chile; ${ }^{3}$ Departamento de Bioquimica y Ciencias Biologicas, Universidad Nacional de San Luis, 5700 San Luis, Argentina; ${ }^{4}$ Department of Biology, University of California, Riverside, California 92521

Accepted 1/20/04

Online enhancement: appendix.

\section{ABSTRACT}

We tested the hypotheses that relative medullary thickness (RMT) and kidney mass are positively related to habitat aridity in rodents, after controlling for correlations with body mass. Body mass, mass-corrected kidney mass, mass-corrected RMT, mass-corrected maximum urine concentration, and habitat (scored on a semiquantitative scale of 1-4 to indicate increasing aridity) all showed statistically significant phylogenetic signal. Body mass varied significantly among habitats, with the main difference being that aquatic species are larger than those from other habitats. Mass-corrected RMT and urine concentration showed a significant positive correlation $(N=38$; conventional $r=0.649$, phylogenetically independent contrasts [IC] $r=$ 0.685), thus validating RMT as a comparative index of urine concentrating ability. RMT scaled with body mass to an exponent significantly less than $0(N=141$ species; conventional allometric slope $=-0.145[95 \%$ confidence interval $(\mathrm{CI})=$ $-0.172,-0.117]$, IC allometric slope $=-0.132$ [95\% CI $=$ $-0.180,-0.083])$. Kidney mass scaled to an exponent significantly less than unity $(N=104$ species; conventional slope $=0.809 \quad[95 \%$ CI $=0.751,0.868], \quad$ IC slope $=0.773$ $[95 \% \mathrm{CI}=0.676,0.871])$. Both conventional and phylogenetic analysis indicated that RMT varied among habitats, with ro-

\footnotetext{
* Present address: Department of Biology, College of Education, P.O. Box 380, King Faisal University, Al Ahsa 31982, Saudi Arabia.

†Corresponding author; e-mail: tgarland@ucr.edu.
}

Physiological and Biochemical Zoology 77(3):346-365. 2004. (C) 2004 by The University of Chicago. All rights reserved. 1522-2152/2004/7703-3077\$15.00 dents from arid areas having the largest values of RMT. A phylogenetic analysis indicated that mass-corrected kidney mass was positively related to habitat aridity.

\section{Introduction}

Mammalian kidneys have a dominant role in controlling both the volume and concentration of body fluids. The nephron is the functional unit of the kidney and consists of a glomerulus and well-developed loops of Henle. The morphological and vascular organizations of nephrons enable mammals to produce urine that is significantly more concentrated than their own plasma. Some of these nephrons, "long looped nephrons," are characterized by an extended renal medullary papilla (Folk 1974; Bankir and de Rouffignac 1985) that reflects the great length of the loop of Henle. The maximum length of the loop of Henle is directly proportional to medullary thickness (Beuchat 1990, 1993, 1996). Sperber's (1944) work on mammalian kidneys showed a relationship between length of the renal papilla and the availability of drinking water in the natural habitat. Specifically, mammals from arid and semiarid habitats tended to have exceptionally long loops of Henle, as compared with mammals from mesic habitats. Sperber (1944) also proposed the relative medullary thickness as a structural index for quantifying the relative length of the longest loops of Henle. Relative medullary thickness (RMT) is calculated as $(\mathrm{MT} / \mathrm{KS}) \times 10$, where MT (typically in $\mathrm{mm}$ ) is the total thickness of the medulla and KS is kidney size (in $\mathrm{mm}$ ), computed as the cube root of the product of the three linear dimensions of the kidney. Sperber (1944) found that mammals living in arid areas had higher values of RMT than those of similar-sized mammals from more mesic habitats.

According to Gottschalk (1987), Sperber was by no means the first to relate the length of the loop of Henle to urine concentrating ability in mammals. Peter (1909, cited in Gottschalk 1987) had pointed out such a correlation among various species of mammals. The relationship was further evaluated by W. Kuhn and collaborators throughout the 1950s, who demonstrated that the osmolality of the fluids in the loop of Henle increased as they pass the renal medulla in the direction of the tip of the papilla. These authors were the first to propose the countercurrent multiplier system to explain the process by which the urine becomes more concentrated as it passes along the loop of Henle (cited in Gottschalk 1987). According to this 
model, the maximum urine concentrating ability is directly related to the length of the loops of Henle and collecting ducts that traverse the renal medulla and inversely to a nephron's diameter. Schmidt-Nielsen and O'Dell (1961) were the first to demonstrate a quantitative correlation between the relative length of the longest loops of Henle (as reflected by RMT) and the maximum urine concentration in a study that compared nine species of mammals.

Following Schmidt-Nielsen and O'Dell's (1961) seminal study, similar interspecific relationships have been shown in various groups of mammals (e.g., marsupials [Reid and McDonald 1968]; Sylvilagus rabbits [Heisinger and Breitenbach 1969]; cricetid rodents [Heisinger et al. 1973]; dasypodids of the Argentine desert, Chaetophratus vellerous and Dasypus novemcintus [Greegor 1975]; sciurid rodents [Blake 1977]; bats [Geluso 1978]). These studies also demonstrate a general trend for species that inhabit arid and semiarid environments to have high abilities to concentrate urine and also high RMT (see also Schmidt-Nielsen 1964; MacMillen and Lee 1967, 1969; Purohit 1974a; Borut and Shkolnik 1974).

In addition to RMT, several other morphometric indices have been proposed to estimate renal performance (Heisinger and Breitenbach 1969; Schmid 1972; Brownfield and Wunder 1976). In all cases, higher indices are typical of small desert mammals. However, RMT is the index most commonly reported in the literature (Beuchat 1996 and references cited therein). Beuchat (1996) compiled a comprehensive set of data from the literature on renal structure and function for 330 species of mammals. Among other goals, she sought to examine the influence of both body mass and habitat on kidney mass and RMT. Considering all mammals, conventional least squares linear regression analysis indicated that kidney mass scaled on body mass with a slope of 0.88 , which is significantly less than unity and similar to values previously reported (Calder and Braun 1983). Interestingly, both RMT and maximum urine concentration scaled negatively with body mass (i.e., larger-bodied species had lower values), with slopes of -0.11 and -0.09 , respectively. When considering the effect of habitat (with body mass as a covariate), mammals from arid habitats tended to have greater RMT and maximum urine concentration, as compared with those from mesic and freshwater habitats. Absolute medullary thickness gave similar results when tested across habitats. Hence, allometric relationships for RMT and urine concentrating ability have been developed separately for mammals from mesic (Blake 1977; Beuchat 1996) and xeric environments (Calder and Braun 1983; Beuchat 1996).

Beuchat (1996) also reported a positive and highly statistically significant relationship between maximum urine osmolality and RMT across 78 species of mammals (her Fig. 8). However, she also reported that both traits show a negative allometric relationship with body mass (her Figs. 4, 5). Thus, the two traits might be related simply because both are correlated with body mass. This can be tested by correlating re- siduals from the log-log regressions of each trait on body mass, but Beuchat (1996) did not report such an analysis. She did, however, report analyses for residuals of total, outer, and inner medulla thicknesses, some of which showed significant relationships with urine concentration (her Figs. 6, 7).

Aside from the issue of correcting for effects of body size, numerous studies over the past 20 years have shown that conventional statistical methods can be misleading when applied to comparative data (see, e.g., reviews in Pagel 1992; Garland et al. 1992, 1993, 1999; Garland and Ives 2000; Rohlf 2001; Rezende and Garland 2003). The existence of hierarchical phylogenetic relationships implies that data for different species cannot be considered as independent and identically distributed for purposes of statistical analyses. Ignoring phylogenetic relationships often leads to inflated Type I error rates (significant relationships are claimed too frequently) and poor estimates of parameters (e.g., slopes of allometric relationships). Moreover, studies that compare species sampled broadly with respect to phylogenetic relationships run the risk of comparing "apples and oranges" (see, e.g., Huey and Bennett 1990; Garland and Adolph 1994; Garland 2001).

The purpose of this article is to examine both RMT and kidney mass in relation to body size, habitat, and phylogeny within one clade of mammals, the Rodentia. We hypothesized that both RMT and kidney mass, corrected for body size, would correlate positively with habitat aridity and that all traits would show phylogenetic signal, that is, the tendency for related species to resemble each other (Blomberg and Garland 2002). We considered only rodents for several reasons. First, by focusing on a single lineage of mammals, we hoped to avoid comparing "apples and oranges." Second, the order Rodentia includes more than 2,000 species, which represent about half of the extant mammals (Wilson and Reeder 1993). Third, extant Rodentia vary widely in body mass, spanning approximately four orders of magnitude. Fourth, they vary widely in life-history strategies and patterns of evolutionary adaptation to different environmental settings (Eisenberg 1981). Fifth, rodents occupy a variety of habitats, and many species, representing several different evolutionary lineages (clades), inhabit arid environments. This is important because multiple evolutionary origins of a feature (e.g., occupancy of arid habitats) within a lineage increase statistical power to detect relationships with other features (e.g., RMT) in comparative studies (Garland et al. 1993; Vanhooydonck and Van Damme 1999). Sixth, more kidney data are available for Rodentia than for any other mammalian order (see Beuchat 1996). Seventh, rodents exhibit a wide range of both urine concentrating ability and RMT, which will enhance statistical power. Finally, the Rodentia has received intense scrutiny from molecular systematists in recent years, which allows construction of a reasonably well resolved estimate of phylogenetic relationships.

We greatly expand the database as compared with Beuchat (1996) by including information from several studies that were 
either not included in her paper or have been published subsequently, and by presenting new data for Argentinean and Chilean rodents, emphasizing species that occur in arid habitats. In total, we consider data for kidney mass of 104 species, only 28 of which were in Beuchat's (1996) paper, and RMT of 141 species, of which 55 were in her paper. In addition, as noted above, Beuchat's (1996) demonstration of a positive relationship between maximum urine concentration and RMT is suspect because (1) she did not use regression residuals to remove negative correlations of both traits with body mass and (2) she did not account for phylogenetic relationships among species. Therefore, we reanalyze the same data that she used but correct both of these deficiencies. We also apply new methods to quantify and to test for the statistical significance of phylogenetic signal in all traits (Blomberg et al. 2003). These methods provide a guide as to whether results of conventional or phylogenetically based statistical methods should be more reliable for a given data set (see also Freckleton et al. 2002).

\section{Material and Methods}

\section{Data Collection}

We gathered new data on rodents from Argentina (E.C.-V. and C.Z.: 14 species from several arid localities) and Chile (C.Z.: 37 species from both arid and mesic localities; collecting localities are available from the authors on request). Sample size and sex ratio varied among species (see App. A), but we did not attempt to correct for this in subsequent statistical analyses because this information was often not available for the literature values (see below). For these new data, habitat assignments (see below) were based on the actual collecting localities, not general literature descriptions. Scientific names are according to Wilson and Reeder (1993) and Redford and Eisenberg (1992). Exceptions were sigmodontine species inhabiting Salta and Catamarca provinces, for which we used nomenclature recommendations of Mares et al. (1989) and Mares et al. (1997), respectively. Chilean rodents were captured from both mesic and xeric habitats. Species names follow Wilson and Reeder (1993), but Eligmodontia, Phyllotis, and Abrothrix are named according to Spotorno et al. (1990, 1994, 2000) and Kelt et al. (1991). We also included the new species Loxodontomys pikumche (Spotorno et al. 1998).

For the new data, kidneys from only adult animals and from only one locality were examined. Length and breadth of kidneys were measured with a vernier $( \pm 0.1 \mathrm{~mm})$ and sagittal halfsectioned (Cortes et al. 1990). Total width and the medullary thickness of the kidney were measured in sagittal slices from the cortex-medullar tips to the extreme of the papilla (Heisinger and Breitenbach 1969; Blake 1977) under a Wild M3 microscope. Midsagittal cuts were made to maximize the area of visualization of the medulla. RMT was calculated following Sperber (1944):

$$
\text { RMT }=\frac{10(\text { medullary thickness })}{(\text { length } \times \text { breadth } \times \text { width })^{1 / 3}} .
$$

Body mass of individuals was obtained from field records, when available; otherwise, a mean value cited in the literature was used (Redford and Eisenberg 1992; Silva and Downing 1995).

For other species (or populations), data for body mass, total mass of both kidneys, RMT, and habitat were taken from the literature. All values cited by Beuchat (1996) were checked, and the original sources are cited in Appendix A, with a few exceptions. When body mass was not reported, an estimate of average adult body mass was obtained from field guides and a variety of other sources. Most common and scientific species names follow Beuchat (1996) or Musser and Carleton (1993). All of the reported measures are for adults. Habitat was recorded as aquatic (A), mesic (M), semidesert (SD, similar to Beuchat's [1996] listing of "DM" for arid and mesic), or desert (D), which corresponds to a rank-ordering of aridity on a scale of 1-4. (For statistical analyses and figures, species listed as DM were pooled into the SD category.) We tried to obtain habitat information from the same study from which other data were collected but used other sources, including field guides, when necessary. Such categorizations can be criticized because of their crude and potentially misleading nature (Leroi et al. 1994), but this should primarily reduce statistical power to detect associations, if they exist. As will be shown, our analyses were in fact able to demonstrate associations with habitat. Clearly, an improvement for future studies would be to obtain quantitative environmental measurements from at or near the capture sites of each species (Tieleman et al. 2003; Rezende et al. 2004).

\section{Phylogenetic Relationships}

The final data set included 164 species, subspecies, or populations of rodents, ranging in body mass from $6 \mathrm{~g}$ to $53 \mathrm{~kg}$. The overall estimate of phylogeny used in statistical analyses was derived from the literature, as detailed in Appendix B in the online edition of Physiological and Biochemical Zoology. Most of this phylogenetic information is from molecular-based studies, with morphological studies used when such was unavailable. When no phylogenetic information was available for a particular species, it was placed beside congeners as a polytomy, which was assumed to be "hard" (i.e., to reflect simultaneous speciation events) for purposes of phylogenetic statistical analyses (Purvis and Garland 1993; Garland and Díaz-Uriarte 1999). For each analysis, we then pruned the tree to include only those species for which data were available (maximum urine concentration, $N=38$; kidney mass, $N=$ 104; RMT, $N=141$ ).

Where it was possible and warranted to keep separate studies 
of a given species as separate data points (tips on the phylogeny), we did so. For example, both Akodon albiventer and Abrothrix andinus were sampled from both Argentina and Chile (new data from our study) and so were kept separate. For cases in which a given species is represented by only two "populations" in the data set, the phylogeny is obvious (i.e., a bifurcation). For three species, we had data on more than two populations for a given trait (three for Phyllotis xanthopygus, three for Peromyscus leucopus, five for Acomys cahirinus). In all of these cases, the samples came from geographically separate localities and so were retained as separate data points. Within each of these species, the phylogenetic relationships were treated as "hard" polytomies; thus, as in conventional statistical analyses, the separate populations were given equal weight relative to each other in phylogenetic analyses (see "Statistical Analyses").

Because estimates of divergence times were not available for all taxa included in the data sets, we tried three different types of arbitrary branch lengths: all equal in length (constant); Grafen's (1989), where each node is set to a depth that is one less than the number of tips that descend from it; and Pagel's (1992), where all branches are initially set to unity and then the lengths of all branches that lead to tips (terminal taxa) are extended to make all tips contemporaneous. The adequacy of branch lengths can be checked in several ways. The most commonly used one is plotting the absolute value of the standardized phylogenetically independent contrasts versus their standard deviations and testing for a significant correlation, which would indicate that the branch lengths are inadequate (Garland et al. 1992; Garland and Díaz-Uriarte 1999). Another approach is to compare the variance of the contrasts or, in the generalized least squares mode of operation (see Blomberg et al. 2003), the mean squared error, with lower values indicating better fit of the tree to the data. Based on these two procedures, we used Pagel's (1992) arbitrary branch lengths for all analyses, including tests for phylogenetic signal. The actual trees used, with branch lengths, are reported in standard bracket format in Appendix $B$ and are available as PDI files (as output by the PDTREE program) from T.G.

\section{Statistical Analyses}

All traits (except habitat) were $\log _{10}$ transformed before analyses. For completeness and to facilitate comparisons with previous studies, we used both conventional and phylogenetically based statistical analyses (reviews in Garland et al. 1999; Garland and Ives 2000; Rohlf 2001). Whether conventional or phylogenetically based results should be given greater credence depends to a large extent on whether the traits in question exhibit significant phylogenetic signal, that is, a tendency for related species to resemble each other (Blomberg and Garland 2002; see also Freckleton et al. 2002). To determine whether traits showed significant phy- logenetic signal, we used the randomization test (1,000 permutations) implemented in the MatLab program PHYSIG.M of Blomberg et al. (2003; http://www.biology.ucr.edu/people/ faculty/Garland/PHYSIG.html). We analyzed habitat (scored on the semiquantitative 1-4 scale), log body mass, and the logs of mass-corrected maximum urine concentration, kidney mass, and RMT. To compute mass-corrected values, we first computed the allometric scaling exponent with independent contrasts. We divided the trait (kidney mass or RMT) by body mass raised to this exponent and then took the logarithm (following Blomberg et al. 2003; an equivalent procedure is to use the "residuals" described on screen 9D of PDTREE [see below] and optionally saved in a file with extension .RSD). This procedure thus uses the phylogenetically correct estimate of the scaling relationship to adjust for correlations with body mass. We also report $K$ (Blomberg et al. 2003), a descriptive statistic that indicates the amount of phylogenetic signal in a trait relative to the amount that would be expected for the specified phylogenetic tree (topology and branch lengths) and given a Brownian motion (random walk in continuous time) model of evolution. A $K$ of 1 indicates that a trait has exactly the amount of signal expected, whereas values greater than 1 indicate more and values less than 1 indicate less signal than expected. The $K$ statistic is useful for comparing the amount of signal in traits of different types (for a survey of traits from various published studies, see Blomberg et al. 2003).

Allometric equations and residuals from them were computed both the conventional way (using SPSS) and with phylogenetically independent contrasts (Felsenstein 1985; Garland et al. 1992; Garland and Adolph 1994). Assuming that the topology and branch lengths are correct, this algorithm leads to a phylogenetically independent data set consisting of $\mathrm{N}-$ 1 standardized contrasts for $N$ original species (tips on the phylogenetic tree). Correlations and regressions with independent contrasts are computed through the origin (Felsenstein 1985; Garland et al. 1992), so degrees of freedom are the same as for conventional statistics. Independent contrasts were computed with the PDTREE module of the Phenotypic Diversity Analysis Programs (Garland et al. 1993, 1999; Garland and Ives 2000; http://www.biology.ucr.edu/people/faculty/Garland/ PDAP.html). We computed $y$-intercepts and confidence intervals (CIs) following Garland and Ives (2000), as implemented in PDTREE for bivariate regressions and as implemented in REGRESSION.M (Blomberg et al. 2003) for multiple regressions.

To determine the relationship between maximum urine concentration and RMT, we used data for 38 species for which both variables were available ( 34 of these were in Beuchat 1996; the following values were added: Neotoma albigula, 2,670 $\mathrm{mmol} / \mathrm{kg} \mathrm{H}_{2} \mathrm{O}$ [Brownfield and Wunder 1976]; Gerbillurus setzeri, 5,370, and Gerbillurus paeba, 4,840 [Downs and Perrin 1991; Frean et al. 1998]; Thallamys nigricauda, 7,630 [Frean et al. 1998]). We then computed residuals from least squares linear 
regressions of each trait on body mass. We regressed (through the origin) standardized contrasts in $\log _{10}$ urine concentration on contrasts in $\log _{10}$ (body mass), then computed residuals, and did the same for $\log _{10}$ RMT. We then computed the correlation (through the origin) for residual contrasts in urine concentration and RMT.

We analyzed the effect of habitat in two ways. First, we treated habitat as a categorical variable and used ANCOVA to test for the relationship between kidney mass and habitat and between RMT and habitat, with body mass as a covariate. ANCOVA was computed in the conventional way (using SPSS) and via Monte Carlo computer simulations to construct phylogenetically informed null distributions of $F$ statistics (Garland et al. 1993; PDAP modules PDSINGLE, PDSIMUL, PDANOVA). Using biologically realistic ranges for body mass, RMT, and kidney mass (on the $\log _{10}$ scales), we performed 1,000 simulations under a gradual Brownian motion model (Felsenstein 1985) but with limits to character evolution. Following most previous uses of PDSIMUL (e.g., Garland et al. 1993; Cruz-Neto et al. 2001; Hutcheon et al. 2002), we used the Replace option to implement limits. For body mass, we used a lower limit of 2 $\mathrm{g}$ and an upper limit of $100 \mathrm{~kg}$. The former is slightly lower than the smallest body mass in our data, Arizona pocket mouse (Perognathus amplus), and the latter is roughly twice the mass of the largest extant rodent, the Capybara (Hydrochaeris hydrochaeris). We used a lower limit of 1 and an upper limit of 20 for RMT. The former is the smallest possible value of RMT, and the latter is slightly higher than the greatest RMT value in our data set, 17.6 for the desert pocket mouse (Chaetodipus penicillatus). The lower limit used for kidney mass was $0.05 \mathrm{~g}$, and the upper limit was $100 \mathrm{~g}$. The lower limit is below the smallest kidney mass in our data set ( $0.08 \mathrm{~g}$ for Mus musculus), and the upper limit is above the largest kidney mass (69.75 $\mathrm{g}$ for Hydrochaeris hydrochaeris). Starting values for all simulations were the defaults in PDSIMUL, which are the conventional means of the characters. The correlation between the two traits (log [body mass] and either $\log$ RMT or $\log$ [kidney mass]) was set to 0 so that we could test the null hypothesis of no effect of body mass.

Second, we treated habitat as a semiquantitative variable. Here, we performed multiple regressions (either conventional or with phylogenetically independent contrasts) of kidney mass or RMT on both body mass and habitat, and we report the one-tailed $P$ value for habitat because we had the directional hypothesis that animals from more arid habitats would have larger kidneys and/or higher RMT after controlling for effects of body mass. This latter approach should increase statistical power to detect an effect of habitat (see, e.g., discussion in Garland et al. 1993) unless the 1-4 scale is very imprecise and/ or far from being a linear approximation of variation in selective regime that is caused by variation in habitat aridity.

\section{Results}

\section{Phylogenetic Signal}

All traits showed statistically significant phylogenetic signal. For the data set that included body mass, RMT, and maximum urine concentration $\left(N=38\right.$, all $\log _{10}$ transformed), $P$ values were $<0.001,0.002$, and 0.008 , respectively, with corresponding $K$ values of $0.658,0.452$, and 0.362 . Signal was also present for $\log _{10}$ of mass-corrected RMT $(P=0.005, K=0.358)$ and maximum urine concentration $(P=0.024, K=0.331)$.

For the 141 species in the RMT data set, body mass, RMT, and mass-corrected RMT (all $\log _{10}$ ) all showed signal at $P<$ 0.001 , and $K$ values were $0.678,0.302$, and 0.192 , respectively. For the 104 species in the kidney mass data set, again all traits showed signal at $P<0.001$, with $K$ values of 0.551 for $\log _{10}$ (body mass), 0.485 for $\log _{10}$ (kidney mass), and 0.200 for $\log _{10}$ (mass-corrected kidney mass).

Finally, habitat (scored on the semiquantitative 1-4 scale) showed highly significant signal $(P<0.001)$ for both the 141and 104-species data sets, with $K$ values of 0.344 and 0.279 , respectively. The presence of significant phylogenetic signal in all traits offers justification for the use of phylogenetically based statistical methods and suggests that results from those methods should be more reliable than those from conventional analyses.

\section{Body Mass in Relation to Habitat}

Considering the 141 species for which RMT data were available, conventional ANOVA indicated a highly significant difference among habitats $\left(F_{3,140}=16.91, P<0.00005\right)$, and this was also significant in comparison with the $F$ values from phylogenetically simulated data (critical $F=6.46, P<0.001$ ). As can be seen in Figure 1, mean $\log _{10}$ (body masses) (kg) of the aquatic species $(0.625$ [ $95 \%$ confidence interval $=-0.507$ to 1.757 ], $N=5)$ averaged much greater than those of the mesic $(-0.907$ $[-1.133$ to -0.682$], N=40)$, semidesert $(-1.310[-1.591$ to $-1.030], N=22)$, or desert species $(-1.262[-1.387$ to -1.138], $N=74$ ), and Scheffé's multiple range comparison indicated that aquatic species are significantly larger than all other groups.

Treating habitat as a quantitative variable, a conventional regression indicated a highly significant prediction of $\log$ (body mass) $\quad\left(r^{2}=0.147, \quad F_{1,139}=24.0\right.$, two-tailed $P<$ $0.00005)$, and independent contrasts analysis also indicated a significant relationship $\left(r^{2}=0.047, F_{1,139}=6.83\right.$, two-tailed $P=0.0100$ ). Considering only the 90 Muridae (the only family that included all four habitat types), the conventional regression still indicated a significant prediction of log body mass $\left(r^{2}=\right.$ $0.045, F_{1,88}=4.17$, two-tailed $\left.P=0.0442\right)$, but the independent contrasts analysis did not $\left(r^{2}=0.029, F_{1,88}=2.61\right.$, two-tailed $P=0.1099)$. 


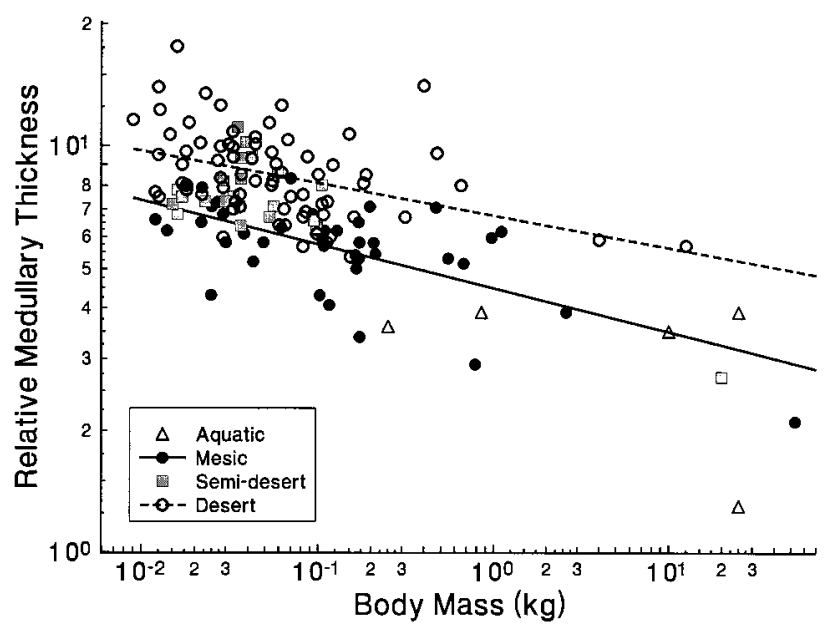

Figure 1. Relative medullary thickness (RMT) in relation to habitat for 141 species or populations of rodents. Conventional least squares linear regressions (fitted to the log-transformed data) are shown as a heuristic for both mesic and desert species. Both conventional and phylogenetically informed ANCOVA indicate significant differences among habitat types in mass-corrected RMT (see text).

\section{Correlation between RMT and Maximum Urine Concentration}

For the subset of 38 species with data for both traits, both urine concentration (UC) and RMT showed a statistically significant negative scaling with body mass. The conventional allometric equations were (95\% confidence intervals are given in parentheses; body mass $\left[M_{\mathrm{b}}\right]$ units are kilograms):

$$
\begin{gathered}
\log _{10} \mathrm{UC}\left(\mathrm{mmol} / \mathrm{kg} \mathrm{H} \mathrm{H}_{2} \mathrm{O}\right)=3.29(3.16,3.42) \\
-0.301(-0.404,-0.197) \times \log _{10} M_{\mathrm{b}}
\end{gathered}
$$

$\left(r^{2}=0.493, F_{1,36}=35.0, P<0.00005\right)$ and

$$
\begin{gathered}
\log _{10} \text { RMT }=0.663(0.572,0.754) \\
-0.185(-0.258,-0.111) \times \log _{10} M_{\mathrm{b}}
\end{gathered}
$$

$\left(r^{2}=0.420, F_{1,36}=26.0, P<0.00005\right)$. Residuals from these regression equations showed a highly significant positive relationship $(r=0.649$, two-tailed $P<0.00005)$.

The independent contrasts allometric equations were similar in terms of slopes and intercepts, although, as expected (see Garland and Ives 2000), the 95\% confidence intervals were wider:

$$
\begin{gathered}
\log _{10} \mathrm{UC}(\mathrm{mmol} / \mathrm{kg} \mathrm{H} \mathrm{O})=3.24(2.82,3.66) \\
-0.368(-0.514,-0.222) \times \log _{10} M_{\mathrm{b}}
\end{gathered}
$$

$$
\left(r^{2}=0.421, F_{1,36}=26.2, P<0.00005\right) \text { and }
$$

$$
\begin{gathered}
\log _{10} \mathrm{RMT}=0.669(0.388,0.950) \\
-0.180(-0.277,-0.082) \times \log _{10} M_{\mathrm{b}}
\end{gathered}
$$

$\left(r^{2}=0.280, F_{1,36}=14.0, P=0.0006\right)$. Again, residuals from these independent contrasts allometric equations showed a highly significant positive relationship $(r=0.685, \quad P<$ $0.00005)$. Thus, both conventional and phylogenetic analyses validate the use of RMT as an indicator of interspecific variation in maximum urine concentrating ability in rodents.

\section{RMT in Relation to Body Mass and Habitat}

Considering all 141 data points, the conventional allometric equation was (95\% confidence intervals are given in parentheses):

$$
\begin{gathered}
\log _{10} \text { RMT }=0.612(0.658,0.730) \\
-0.145(-0.172,-0.118) \times \log _{10} M_{\mathrm{b}}
\end{gathered}
$$

$\left(r^{2}=0.440, F_{1,139}=109.4, P<0.00005\right)$. The independent contrasts allometric equation was similar in terms of slope and intercept:

$$
\begin{gathered}
\log _{10} \text { RMT }=0.699(0.473,0.925) \\
-0.132(-0.180,-0.083) \times \log _{10} M_{\mathrm{b}}
\end{gathered}
$$

$\left(r^{2}=0.172, F_{1,139}=28.8, P<0.00005\right)$.

In the conventional ANCOVA of habitat groups, $\log M_{\mathrm{b}}$ had a highly significant $(P<0.001)$ negative effect on $\log$ RMT (pooled within-groups slope $=-0.102$ ), which also differed significantly among habitats $(P<0.001)$, with desert rodents having the highest RMT values, followed by semidesert rodents, then mesic rodents, and finally aquatic animals (Fig. 1; Table 1). Critical $F$ values obtained from the Monte Carlo simulations were, as expected, higher than conventional values, but the effects of both body mass and habitat were still significant (Table 1). The interaction between log body mass and habitat was not significant $(P=0.63)$.

The multiple regression approach, which treated habitat as a quantitative variable, also indicates that it was a significant predictor of RMT. The conventional multiple regression yielded 
Table 1: ANCOVA comparing log RMT for 141 rodents from different habitats (arid, semiarid, mesic, aquatic) with log body mass $(\mathrm{kg})$ as the covariate

\begin{tabular}{|c|c|c|c|c|c|c|c|c|}
\hline \multirow[b]{2}{*}{$\begin{array}{l}\text { Source of } \\
\text { Variation }\end{array}$} & \multirow[b]{2}{*}{$\begin{array}{l}\text { Sum of } \\
\text { Squares }\end{array}$} & \multirow[b]{2}{*}{$\mathrm{df}$} & \multirow[b]{2}{*}{$\begin{array}{l}\text { Mean } \\
\text { Square }\end{array}$} & \multirow[b]{2}{*}{$F$} & \multicolumn{2}{|c|}{ Conventional } & \multicolumn{2}{|c|}{ Phylogenetic } \\
\hline & & & & & $\begin{array}{l}\text { Critical } \\
\text { Value }\end{array}$ & $P$ & $\begin{array}{l}\text { Critical } \\
\text { Value }\end{array}$ & $P$ \\
\hline Habitat & .616 & 3 & .205 & 21.70 & 2.67 & $<.001$ & 5.75 & $<.001$ \\
\hline $\log$ (body mass) & .544 & 1 & .544 & 57.44 & 3.91 & $<.001$ & 40.65 & .025 \\
\hline Explained & 2.114 & 4 & .529 & 55.82 & 2.44 & $<.001$ & 12.74 & $<.001$ \\
\hline Error & 1.288 & 136 & .009 & & & & & \\
\hline Total & 3.402 & 140 & .024 & & & & & \\
\hline
\end{tabular}

the following predictive equation (habitat is scored on a $1-4$ scale):

$$
\begin{gathered}
\log _{10} \mathrm{RMT}=0.500(0.445,0.556) \\
-0.107(-0.131,-0.082) \times \log _{10} M_{\mathrm{b}} \\
(\text { one-tailed } P<0.00005) \\
+0.074(0.056,0.092) \times \text { habitat }
\end{gathered}
$$

(one-tailed $P<0.00005$ )

(multiple $\left.r^{2}=0.619, F_{2,138}=112.3, P<0.00005\right)$. The independent contrasts equation was

$$
\begin{gathered}
\log _{10} \mathrm{RMT}=0.478(\mathrm{SE}=0.1051434) \\
-0.100(-0.143,-0.057) \times \log _{10} M_{\mathrm{b}} \\
(\text { one-tailed } P<0.00005) \\
+0.082(0.058,0.106) \times \text { habitat } \\
\text { (one-tailed } P<0.00005)
\end{gathered}
$$

(multiple $r^{2}=0.374, F_{2,138}=41.3, P<0.00005$ ). Repeating these analyses for the 90 Muridae only yielded a conventional multiple regression of

$$
\begin{gathered}
\log _{10} \mathrm{RMT}=0.470(0.384,0.557) \\
-0.103(-0.153,-0.054) \times \log _{10} M_{\mathrm{b}} \\
(\text { one-tailed } P=0.0001) \\
+0.080(0.059,0.100) \times \text { habitat }
\end{gathered}
$$

(one-tailed $P<0.00005$ ) (multiple $r^{2}=0.523, F_{2,87}=47.8, P<0.00005$ ). The independent contrasts equation was

$$
\begin{gathered}
\log _{10} \mathrm{RMT}=0.516(\mathrm{SE}=0.085537) \\
-0.056(-0.121,0.001) \times \log _{10} M_{\mathrm{b}} \\
(\text { one-tailed } P=0.0475) \\
+0.088(0.065,0.111) \times \text { habitat } \\
(\text { one-tailed } P<0.00005)
\end{gathered}
$$

(multiple $r^{2}=0.431, F_{2,87}=32.9, P<0.00005$ ).

\section{Kidney Mass in Relation to Body Mass and Habitat}

Considering all 104 data points, the conventional allometric equation was ( $95 \%$ confidence intervals are given in parentheses):

$$
\begin{gathered}
\log _{10}(\text { kidney mass })(\mathrm{g})=0.723(0.646,0.799) \\
+0.809(0.751,0.868) \times \log _{10} M_{\mathrm{b}}
\end{gathered}
$$

$\left(r^{2}=0.881, F_{1,102}=756.0, P<0.00005\right)$. Parameters of the independent contrasts allometric equation were similar:

$$
\begin{gathered}
\log _{10}(\text { kidney mass })(\mathrm{g})=0.680(0.310,1.049) \\
+0.773(0.676,0.871) \times \log _{10} M_{\mathrm{b}}
\end{gathered}
$$$$
\left(r^{2}=0.710, F_{1,102}=249.4, P<0.00005\right) .
$$

In the conventional ANCOVA of habitat groups (Table 2), $\log M_{\mathrm{b}}$ had a highly significant $(P<0.001)$ positive effect on $\log$ (kidney mass) (pooled within-groups slope $=-0.803$ ), but habitat had no effect ( $P=0.318$; see Fig. 2$)$. Comparison of $F$ ratios with those obtained from the Monte Carlo simulations leads to similar conclusions (Table 2; the interaction between $\log M_{\mathrm{b}}$ and habitat was not significant, $P=0.89$ ). 
Table 2: ANCOVA comparing $\log$ (kidney mass) (g) for 103 rodents from different habitats (arid, semiarid, mesic) with $\log$ (body mass) $(\mathrm{kg})$ as the covariate

\begin{tabular}{|c|c|c|c|c|c|c|c|c|}
\hline \multirow[b]{2}{*}{$\begin{array}{l}\text { Source of } \\
\text { Variation }\end{array}$} & \multirow[b]{2}{*}{$\begin{array}{l}\text { Sum of } \\
\text { Squares }\end{array}$} & \multirow[b]{2}{*}{ df } & \multirow[b]{2}{*}{$\begin{array}{l}\text { Mean } \\
\text { Square }\end{array}$} & \multirow[b]{2}{*}{$F$} & \multicolumn{2}{|c|}{ Conventional } & \multicolumn{2}{|c|}{ Phylogenetic } \\
\hline & & & & & $\begin{array}{l}\text { Critical } \\
\text { Value }\end{array}$ & $P$ & $\begin{array}{l}\text { Critical } \\
\text { Value }\end{array}$ & $P$ \\
\hline Habitat & .075 & 2 & .038 & 1.16 & 3.09 & .318 & 8.27 & .664 \\
\hline $\log$ (body mass) & 21.198 & 1 & 21.198 & 652.76 & 3.94 & $<.001$ & 32.03 & $<.001$ \\
\hline Explained & 23.573 & 3 & 7.858 & 241.96 & 2.70 & $<.001$ & 14.89 & $<.001$ \\
\hline Error & 3.215 & 99 & .032 & & & & & \\
\hline Total & 26.788 & 102 & .263 & & & & & \\
\hline
\end{tabular}

Note. Only one species was categorized as aquatic, so this category and data point were excluded.

In the conventional multiple regression, habitat was not a significant predictor of kidney mass:

$$
\begin{gathered}
\log _{10}(\text { kidney mass })(\mathrm{g})=0.698(0.572,0.824) \\
+0.814(0.752,0.876) \times \log _{10} M_{\mathrm{b}} \\
\quad(\text { one-tailed } P<0.00005) \\
+0.010(-0.030,0.050) \times \text { habitat } \\
\quad \text { (one-tailed } P=0.3107)
\end{gathered}
$$

(multiple $r^{2}=0.881, F_{2,101}=375.3, P<0.00005$ ).

However, with phylogenetically independent contrasts, both body mass and habitat were significant:

$$
\begin{gathered}
\log _{10}(\text { kidney mass })(\mathrm{g})=0.575(\mathrm{SE}=0.192949) \\
+0.793(0.695,0.892) \times \log _{10} M_{\mathrm{b}} \\
\quad(\text { one-tailed } P<0.00005) \\
+0.042(-0.003,0.088) \times \text { habitat } \\
\quad(\text { one-tailed } P=0.0346)
\end{gathered}
$$

(multiple $r^{2}=0.719, F_{2,101}=129.3, P<0.00005$ ). When the analysis was repeated for the 71 Muridae only, the conventional multiple regression was

$$
\begin{gathered}
\log _{10}(\text { kidney mass })(\mathrm{g})=0.848(0.604,1.092) \\
+0.870(0.734,1.007) \times \log _{10} M_{\mathrm{b}} \\
(\text { one-tailed } P<0.00005) \\
-0.013(-0.066,0.040) \times \text { habitat } \\
(\text { two-tailed } P=0.6152 \\
\text { sign in wrong direction })
\end{gathered}
$$

(multiple $r^{2}=0.708, F_{2,68}=82.5, P<0.00005$ ). The independent contrasts equation was

$$
\begin{gathered}
\log _{10}(\text { kidney mass })(\mathrm{g})=0.708(\mathrm{SE}=0.21132) \\
+0.890(0.733,1.048) \times \log _{10} M_{\mathrm{b}} \\
(\text { one-tailed } P<0.00005) \\
+0.033(-0.027,0.093) \times \text { habitat } \\
(\text { one-tailed } P=0.1378)
\end{gathered}
$$

(multiple $r^{2}=0.654, F_{2,68}=64.2, P<0.00005$ ).

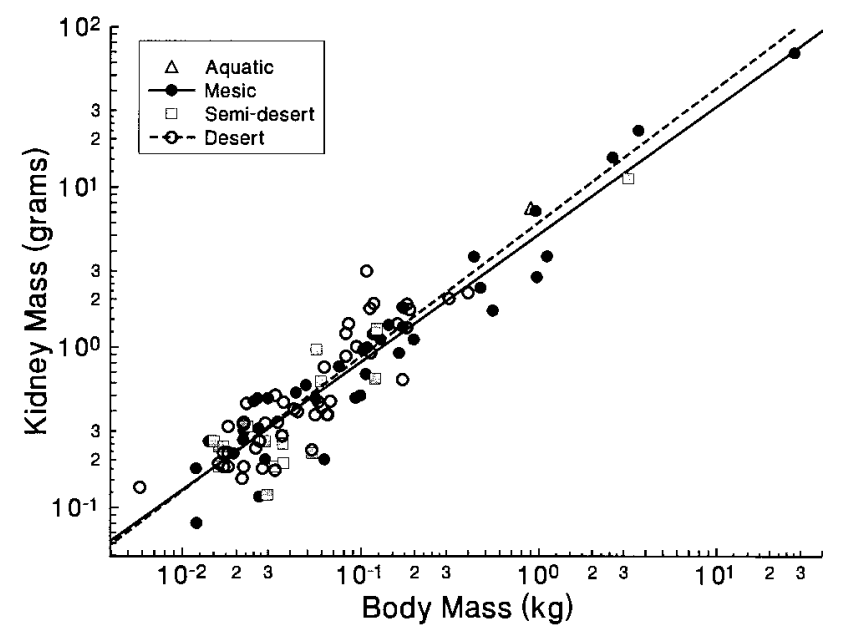

Figure 2. Kidney mass in relation to habitat for 104 species or populations of rodents. Conventional least squares linear regressions (fitted to the log-transformed data) are shown as a heuristic for both mesic and desert species. Both conventional and phylogenetically informed ANCOVA indicate no significant differences among habitat types in mass-corrected kidney mass (see text). However, a phylogenetic analysis that treated habitat as a quantitative variable (scored on a 1-4 scale to indicate increasing aridity) revealed a significant positive relationship between mass-corrected kidney mass and habitat (see text). 


\section{Discussion}

This is the first study to employ an explicitly phylogenetic analysis to examine the effects of body size and of habitat on the most commonly used morphological indicator of mammalian kidney performance, relative medullary thickness (RMT), as well as kidney mass. For reasons presented in the "Introduction," analyses were restricted to a single mammalian lineage, the Rodentia. Phylogenetic signal was statistically significant for all traits examined (including habitat), which suggests that results of phylogenetically informed statistical analyses should be more reliable than conventional analyses (Freckleton et al. 2002; Blomberg et al. 2003). Nevertheless, results of conventional and phylogenetic analyses were largely congruent, with one interesting exception (see below).

Although body mass showed significant phylogenetic signal, as has been reported previously for rodents and other animal groups (Freckleton et al. 2002; Blomberg et al. 2003; Rezende et al. 2004), rodents categorized as aquatic (nutria, beaver, muskrat, water rat) were significantly larger in body mass as compared with species from all other habitat types. Thus, both ecology and phylogeny affect body size. As body size affects virtually all aspects of an organism, various possible adaptive explanations for the large size of aquatic rodents can be hypothesized. For example, natural selection in aquatic habitats might favor large size because it lowers surface/volume ratios, which in turn confer lower mass-specific rates of heat loss. Another possibility is that aquatic habitats tend to offer higher primary productivity, which leads to selection that favors large body size. Alternatively, an aquatic lifestyle may reduce constraints on body size that relate to locomotor biomechanics.

After correcting for correlations with body mass, RMT was a highly significant predictor of maximum urine concentrating ability, thus bolstering its use as a comparative indicator of mammalian kidney performance. Consistent with previous studies, we found that RMT scaled negatively with body mass and that kidney mass scaled with an exponent significantly less than unity, such that larger-bodied species of rodents generally have lower values for RMT and relatively smaller kidneys. We also found that RMT (corrected for body size) varies significantly among habitats, with species from arid habitats having higher RMT, as would be expected since the pioneering work of Sperber (1944; see "Introduction").

Kidney mass (corrected for body size) tended to increase with increasing habitat aridity (scored on a semiquantitative scale), which was statistically significant in the phylogenetic analysis (one-tailed $P=0.0346$ ) but not in the conventional analysis (one-tailed $P=0.3107$ ). Because the $P$ value for habitat differed greatly between conventional and phylogenetic analyses, we checked for outliers and/or influential points in both (e.g., magnitude of standardized residual, leverage). The conventional regression did not yield any noteworthy residuals (e.g., all standardized residuals were $<3.0$ in magnitude). The largest standardized residual was 2.92 for Parotomys littledalei. The leverage for this data point was not unusually large (0.0141), and the outlier test described in Cook and Weisberg (1999) produced a $P$ value of 0.28 . Similarly, the independent contrasts regression yielded no standardized residuals $>3.0$. The largest value was -2.96 for node 63 on the tree, which contrasts Peromyscus eremicus (habitat D) with the ancestor of two populations of Peromyscus leucopus (one from South Dakota with SD habitat, the other from Pennsylvania with M habitat). The leverage for this point was only 0.0289 , and the outlier test indicated $P=0.24$. Still, the large difference in relative kidney mass between $P$. eremicus ( $0.98 \%$ of body mass) and the average of the two P. leucopus populations $(0.42 \%)$ is noteworthy and suggests that this genus, which shows substantial physiological variability (MacMillen and Garland 1989), would be a good candidate for common-garden comparative studies (Garland and Adolph 1991, 1994; Oswald 1998). This example also demonstrates that phylogenetic analyses can sometimes uncover relationships (yield greater statistical power) that are not evident when phylogeny is ignored.

Comparative phylogenetic analyses seek to elucidate how traits have evolved and are predicated on the assumption that observed differences among species are at least mostly genetically based. However, all of the traits considered here (body mass, kidney mass, RMT) can be affected by environmental conditions experienced from birth (or even before) into adulthood (Bankir et al. 1988; Garland and Adolph 1991; Oswald 1998; Al-kahtani 2003; references therein), and with very few exceptions the data analyzed herein were from wild-caught individuals that must have experienced sometimes immensely different environmental conditions during their ontogeny. Thus, it is possible that a substantial fraction of the interspecific variation that we analyzed could represent direct environmental effects rather than genetically based differences. For example, Al-kahtani (2003) found that chronic water restriction applied to outbred house mice (Hsd:ICR strain) from weaning at 21 $\mathrm{d}$ of age reduced body mass by $50 \%$ at $146 \mathrm{~d}$ of age (mass of free-water group was $36.14 \pm 0.589$ [mean $\pm \mathrm{SE}$ ] g, $N=15$; mass of water-restricted group was $18.21 \pm 0.524 \mathrm{~g}, N=19$ ). For these same individuals, body mass-adjusted kidney mass (from ANCOVA) was significantly increased by $12 \%$ (free-water group averaged $0.459 \pm 0.008$ g vs. $0.512 \pm 0.009 \mathrm{~g}$ ), but RMT was not significantly affected (raw means averaged $0.729 \pm$ $0.028[N=14]$ for the free-water group and $0.726 \pm 0.025$ [ $N=15]$ for the water-restricted group). Although many factors other than water availability can also affect these traits, and it is possible that laboratory house mice are less plastic than some wild rodents, Al-kahtani's (2003) results suggest that the differences among species analyzed in our study cannot represent entirely environmental differences experienced during ontogeny. For example, body mass varies by 9,000 -fold in our sample, relative kidney mass varies by more than twofold even among species of Peromyscus (see previous paragraph), and 
inspection of Appendix A indicates many cases of substantial variation in RMT among species within a single genus (e.g., $26 \%$ among species of Octodon, $33 \%$ among species of Eutamius, $68 \%$ among species of Meriones, $30 \%$ between two species of Cynomys, $82 \%$ between two species of Chaetodipus).

Many previous studies have shown that RMT varies inversely with body size in different groups of mammals (Blake 1977; Greegor 1975; Geluso 1978; Beuchat 1991, 1993, 1996). For example, Beuchat (1991) examined the relationship between body mass and RMT for a taxonomically diverse sample of 165 species of mammals. She reported that both RMT and urine concentrating ability scaled negatively with body mass as: $\mathrm{RMT}=5.408 M^{-0.108}$ and $U_{\text {osm }}=2,564 M^{-0.097}$, respectively. Thus, small mammals have higher RMT and produce more concentrated urine as compared with larger-bodied mammals. Our analyses demonstrate that these conclusions hold for rodents and also that RMT is a significant predictor of maximum urine concentration after controlling statistically for effects of both body size and phylogeny.

It seems a paradox that larger mammals with their absolutely longer loops of Henle are unable to concentrate their urine to the same degree as most small mammals. This pattern is inconsistent with the assumption of a countercurrent multiplier system, which states that the longer loops facilitate the production of more concentrated urine. Greenwald and colleagues (Greenwald and Stetson 1988; Greenwald 1989; Abrahams et al. 1991) have recognized this discrepancy and offered a "metabolic hypothesis" to explain it. This hypothesis is based on the premise that small mammals have a higher mass-specific metabolic rate than larger ones, and hence their absolutely shorter loops are metabolically more active (per unit tissue) than those of large mammals. They have tested this hypothesis with data from several mammals ranging in body mass from a horse of $400 \mathrm{~kg}$ to a bat of $11 \mathrm{~g}$. They concluded that loops of Henle, especially the medullary thick ascending limb (MTAL) of small mammals have (1) more inflodings in the basolateral membrane per unit volume, (2) more mitochondria per unit volume, and (3) more inner mitochondrial membrane per unit volume. These structural modifications are crucial elements in the metabolic rate of ATP production, which drive the active transport of $\mathrm{NaCl}$ in this segment and hence maintain a higher cortical-medullary urine concentration gradient.
In our analysis of rodents, body mass-corrected RMT was positively associated with habitat aridity. This result is consistent with the finding of convergent trends in kidney structure, including a thick medulla relative to kidney size, that have been observed in a variety of lineages of small mammals from diverse desert habitats (e.g., rabbits [Heisinger and Breitenbach 1969], hedgehogs [Yaakobi and Shkolnik 1974], insectivorous bats [Geluso 1978], and heteromyid rodents [MacMillen and Hinds 1983]). However, as noted in the previous paragraph, maximum loop length alone does not determine variation in urine concentrating ability. Other important structural characteristics include the arrangement of vascular bundles (the vasa recta) within the medulla, nephron heterogeneity, the presence of extensions of the renal pelvis into the medulla (specialized pelvic fornices), and the degree of confluence of the collecting ducts in the inner medulla (Dantzler and Braun 1980; Bankir and de Rouffignac 1985; Braun 1998). When data for these traits become available for a greater range of species, it will be of interest to perform analyses similar to what we have done for RMT and kidney mass. It will also be of interest to examine other morphometric indices (e.g., see Brownfield and Wunder 1976) and molecular indicators of kidney function, such as vasopressin binding (Oswald 1998; Al-kahtani 2003).

\section{Acknowledgments}

We thank all of the people (see App. A) who helped by providing additional information about their published studies, Gad Perry for literature assistance and translations, Isabelle Girard for helpful discussions, Scott J. Steppan for advice on phylogenies, and three anonymous reviewers. We also thank Arturo Cortés and F. Murua for help with data collection. Supported by U.S. National Science Foundation grant DEB0196384 to T.G. and A. R. Ives; FONDECYT 196-0382 and 796-0017 from the Fondo Nacional de Ciencia y Tecnología, Chile, to C.Z.; and CyT UNSL (FQBF) 9502 to E.C.-V. M.A.A. was supported by a fellowship from the Educational Mission of the Saudi Arabian Embassy in Washington, D.C., and by funds from the University of Wisconsin-Madison Department of Zoology. 


\section{Appendix A}

Table A1: Body mass, total mass of both kidneys $(N=104)$, relative medullary thickness $(N=141)$, and habitat of rodents

\begin{tabular}{|c|c|c|c|c|c|c|c|c|}
\hline $\begin{array}{l}\text { Tip } \\
\text { Code }\end{array}$ & $\begin{array}{l}\text { Tip } \\
\text { No. }\end{array}$ & $\begin{array}{l}\text { Genus and Species } \\
\text { (Common Name) }\end{array}$ & Family & RMT & $\begin{array}{l}\text { Kidney } \\
\text { Mass } \\
(\mathrm{g})\end{array}$ & $\begin{array}{l}\text { Body } \\
\text { Mass } \\
(\mathrm{kg})\end{array}$ & Habitat & Reference \\
\hline $\mathrm{HC}$ & 1 & $\begin{array}{l}\text { Hystrix cristata (African } \\
\text { porcupine) }\end{array}$ & Hystricidae & 2.7 & & 20 & $\mathrm{DM}$ & Sperber 1944 \\
\hline DP & 2 & $\begin{array}{l}\text { Dolichotis panagonica } \\
\text { (Patagonian cavy) }\end{array}$ & Caviidae & 5.7 & & 12.5 & $\mathrm{D}$ & Sperber 1944 \\
\hline $\mathrm{Mn}$ & 3 & Microcavia niata (Chile; 4,3 ) & Caviidae & 8.1 & 1.86 & .181 & $\mathrm{D}$ & This study (C.Z.) \\
\hline $\mathrm{CZ}$ & 4 & Cavia porcellus (guinea pig) & Caviidae & & 3.698 & .43 & M & Spector 1956 \\
\hline Ap & 5 & $\begin{array}{l}\text { Agouti }(=\text { Cuniculus) paca } \\
\text { virgatus (spotted agouti) }\end{array}$ & Dasyproctidae & & 22.7 & 3.627 & M & Quiring 1950 \\
\hline $\mathrm{Dl}$ & 6 & $\begin{array}{l}\text { Dasyprocta leporina }(=\text { aguti) } \\
\quad(\text { agouti) }\end{array}$ & Dasyproctidae & 3.9 & 15.39 & 2.6 & M & Sperber 1944 \\
\hline $\mathrm{Hh}$ & 7 & $\begin{array}{l}\text { Hydrochaeris hydrochaeris } \\
\qquad(=\text { isthimius }) \text { (capybara) }\end{array}$ & Hydrochoeridae & 2.1 & & 53 & M & Sperber 1944 \\
\hline $\mathrm{HH}$ & 8 & $\begin{array}{l}\text { H. hydrochaeris (= isthimius) } \\
\text { (capybara) }\end{array}$ & Hydrochoeridae & & 69.75 & 27.67 & M & Sperber 1944; Quiring 1950 \\
\hline $\mathrm{aC}$ & 9 & $\begin{array}{l}\text { Abrocoma cinerea (Chile; 0, } \\
\text { 4) }\end{array}$ & Abrocomidae & 6.9 & 1.40 & .085 & $\mathrm{D}$ & This study (C.Z.) \\
\hline $\mathrm{aB}$ & 10 & $\begin{array}{l}\text { Abrocoma bennetti (Chile; } 3 \text {, } \\
\text { 2) }\end{array}$ & Abrocomidae & 7.1 & 1.12 & .197 & M & This study (C.Z.) \\
\hline$c L$ & 11 & $\begin{array}{l}\text { Chinchilla lanígera (Chile; } 4 \text {, } \\
\text { 2) }\end{array}$ & Chinchillidae & 6.7 & 2.02 & .312 & $\mathrm{D}$ & This study (C.Z.) \\
\hline $\mathrm{Cl}$ & 12 & Chinchilla laniger & Chinchillidae & 9.6 & & .475 & $\mathrm{D}$ & $\begin{array}{l}\text { Sperber 1944; Weisser et al. } \\
\quad 1970\end{array}$ \\
\hline My & 13 & Myocastor coypus (nutria) & Capromyidae & 3.5 & & 10 & $\mathrm{~A}$ & Pfeiffer 1970; Sperber 1944 \\
\hline $\mathrm{Ce}$ & 14 & Ctenomys eremophilus & Octodontoidae & 8.98 & & .12118 & $\mathrm{D}$ & Diaz and Ojeda 1999 \\
\hline $\mathrm{O} 2$ & 15 & Octodontomys gliroides $[$ sic $]$ & Octodontoidae & 5.35 & & .153 & $\mathrm{D}$ & Diaz and Ojeda 1999 \\
\hline $\mathrm{Og}$ & 16 & $\begin{array}{l}\text { Octodontomys glyroides } \\
\quad(\text { Chile; } 2,3)\end{array}$ & Octodontoidae & 8.5 & 1.72 & .187 & $\mathrm{D}$ & This study (C.Z.) \\
\hline $\mathrm{Tb}$ & 17 & Tympanoctomys barrerae & Octodontoidae & 9.41 & & .08679 & $\mathrm{D}$ & Diaz and Ojeda 1999 \\
\hline $\mathrm{Om}$ & 18 & Octomys mimax & Octodontoidae & 6.09 & & .09832 & $\mathrm{D}$ & Diaz and Ojeda 1999 \\
\hline $\mathrm{oD}$ & 19 & Octodon degus (Chile; 7, 2) & Octodontoidae & 6.7 & 1.40 & .16 & $\mathrm{D}$ & This study (C.Z.) \\
\hline $\mathrm{oB}$ & 20 & Octodon bridgesi (Chile; 5,3 ) & Octodontoidae & 5.4 & .92 & .163 & M & This study (C.Z.) \\
\hline $\mathrm{oL}$ & 21 & Octodon lunatus (Chile; 2, 0) & Octodontoidae & 5.3 & 1.34 & .171 & M & This study (C.Z.) \\
\hline Af & 22 & $\begin{array}{l}\text { Aconaemys fuscus (Chile; 2, } \\
\text { 1) }\end{array}$ & Octodontoidae & 6.2 & 1.12 & .128 & M & This study (C.Z.) \\
\hline As & 23 & Aconaemys sagei (Chile; 3,0$)$ & Octodontoidae & 5.9 & .68 & .106 & M & This study (C.Z.) \\
\hline S2 & 24 & $\begin{array}{l}\text { Spalacopus cyanus (Chile; } 5 \text {, } \\
\text { 4) }\end{array}$ & Octodontoidae & 6.2 & .50 & .099 & M & This study (C.Z.) \\
\hline $\mathrm{Ci}$ & 25 & $\begin{array}{l}\text { Castor fiber (European } \\
\text { beaver) }\end{array}$ & Castoridae & 3.9 & & 25 & A & Sperber 1944 \\
\hline $\mathrm{Cc}$ & 26 & $\begin{array}{l}\text { Castor canadensis (American } \\
\text { beaver) }\end{array}$ & Castoridae & 1.3 & & 25 & A & $\begin{array}{l}\text { Schmidt-Nielsen and O’Dell } \\
\text { 1961; Munkacsi and } \\
\text { Palkovits } 1977\end{array}$ \\
\hline $\mathrm{Cv}$ & 27 & Ctenodactylus vali (gundi) & Ctenodactylidae & & 1.328 & .18 & $\mathrm{D}$ & de Rouffignac et al. 1981 \\
\hline AR & 28 & $\begin{array}{l}\text { Aplodontia rufa (mountain } \\
\text { beaver) }\end{array}$ & Aplodontoidae & 2.9 & & .785 & M & $\begin{array}{l}\text { Dolph et al. 1962; Nungesser } \\
\text { and Pfeiffer 1965; Sperber } \\
1944\end{array}$ \\
\hline Ts & 29 & $\begin{array}{l}\text { Tamias striatus (eastern } \\
\text { chipmunk) }\end{array}$ & Sciuridae & 6.2 & & .109 & M & Blake 1977 \\
\hline TS & 30 & $\begin{array}{l}\text { T. striatus (eastern } \\
\text { chipmunk) second study }\end{array}$ & Sciuridae & & .756 & .075 & M & Quiring 1950 \\
\hline
\end{tabular}




\begin{tabular}{|c|c|c|c|c|c|c|c|c|}
\hline $\begin{array}{l}\text { Tip } \\
\text { Code }\end{array}$ & $\begin{array}{l}\text { Tip } \\
\text { No. }\end{array}$ & $\begin{array}{l}\text { Genus and Species } \\
\text { (Common Name) }\end{array}$ & Family & RMT & $\begin{array}{l}\text { Kidney } \\
\text { Mass } \\
(\mathrm{g})\end{array}$ & $\begin{array}{l}\text { Body } \\
\text { Mass } \\
(\mathrm{kg})\end{array}$ & Habitat & Reference \\
\hline Es & 31 & $\begin{array}{l}\text { Eutamias speciosus (lodgepole } \\
\text { chipmunk) }\end{array}$ & Sciuridae & 8.32 & & .07 & M & Heller and Poulson 1972 \\
\hline Em & 32 & $\begin{array}{l}\text { Eutamias minimus (least } \\
\text { chipmunk) }\end{array}$ & Sciuridae & 11.1 & & .035 & $\mathrm{DM}$ & Heller and Poulson 1972 \\
\hline EA & 33 & $\begin{array}{l}\text { Eutamias amoenus (yellow- } \\
\text { pine chipmunk) }\end{array}$ & Sciuridae & 9.39 & & .042 & $\mathrm{DM}$ & Heller and Poulson 1972 \\
\hline $\mathrm{Ea}$ & 34 & $\begin{array}{l}\text { Eutamias alpinus (alpine } \\
\text { chipmunk) }\end{array}$ & Sciuridae & 10.2 & & .039 & $\mathrm{DM}$ & Heller and Poulson 1972 \\
\hline $\mathrm{Xi}$ & 35 & $\begin{array}{l}\text { Xerus inauris (African } \\
\text { ground squirrel) }\end{array}$ & Sciuridae & 14.1 & 2.2 & .4 & $\mathrm{D}$ & Marsh et al. 1978 \\
\hline Fp & 36 & $\begin{array}{l}\text { Funambulus pennanti (five- } \\
\text { striped squirrel) }\end{array}$ & Sciuridae & 6.8 & .484 & .0929 & M & $\begin{array}{l}\text { Purohit et al. 1973; Purohit } \\
\text { and Ghosh } 1965\end{array}$ \\
\hline Sp & 37 & $\begin{array}{l}\text { Spermophilus parryii parryii } \\
\text { (arctic ground squirrel) }\end{array}$ & Sciuridae & & 7.12 & .958 & M & Quiring 1950 \\
\hline $\mathrm{Sb}$ & 38 & $\begin{array}{l}\text { Spermophilus beecheyi } \\
\text { (California ground } \\
\text { squirrel) }\end{array}$ & Sciuridae & 7.07 & 2.36 & .468 & M & Baudinette 1974 \\
\hline Sl & 39 & $\begin{array}{l}\text { Spermophilus lateralis } \\
\text { (golden-mantled ground } \\
\text { squirrel) }\end{array}$ & Sciuridae & 5.44 & & .212 & M & $\begin{array}{l}\text { Blake 1977; Munkacsi and } \\
\text { Palkovits } 1977\end{array}$ \\
\hline $\mathrm{Cu}$ & 40 & $\begin{array}{l}\text { Cynomys ludovicianus (black- } \\
\text { tailed prairie dog) }\end{array}$ & Sciuridae & 5.96 & 2.76 & .972 & M & Harlow and Braun 1995 \\
\hline $\mathrm{cl}$ & 41 & $\begin{array}{l}\text { Cynomys leucurus (white- } \\
\text { tailed prairie dog) }\end{array}$ & Sciuridae & 6.17 & 3.72 & 1.11 & M & Harlow and Braun 1995 \\
\hline $\mathrm{TH}$ & 42 & $\begin{array}{l}\text { Tamiasciurus hudsonicus (red } \\
\text { squirrel) }\end{array}$ & Sciuridae & 5.79 & & .207 & M & Bakko 1975 \\
\hline Th & 43 & T. hudsonicus (red squirrel) & Sciuridae & & 1.3815 & .1425 & M & Layne 1954 \\
\hline Sv & 44 & $\begin{array}{l}\text { Sciurus vulgaris (tree } \\
\text { squirrel) }\end{array}$ & Sciuridae & 5.3 & 1.7 & .55 & M & Sperber 1944 \\
\hline $\mathrm{Sc}$ & 45 & $\begin{array}{l}\text { Sciurus carolinensis (gray } \\
\text { squirrel) }\end{array}$ & Sciuridae & 5.15 & & .673 & M & Bakko 1975 \\
\hline $\mathrm{Pc}$ & 46 & $\begin{array}{l}\text { Pedetes capensis }(=\text { caffer }) \\
\quad \text { (spinghare) }\end{array}$ & Pedetidae & 5.9 & & 4 & $\mathrm{D}$ & Sperber 1944 \\
\hline $\mathrm{P} 2$ & 47 & P. capensis (springhare) & Pedetidae & & 11.37 & 3.18 & SD & Butynski 1979 \\
\hline DG & 48 & Geomys pinetis & Geomyidae & 5 & & .165 & M & $\begin{array}{l}\text { Sperber 1944; Hickman and } \\
\text { Brown } 1973\end{array}$ \\
\hline Mp & 49 & $\begin{array}{l}\text { Microdipodops pallidus (pale } \\
\text { kangaroo mouse) }\end{array}$ & Heteromyidae & 9.52 & & .0125 & $\mathrm{D}$ & Lawler and Geluso 1986 \\
\hline $\mathrm{Dd}$ & 50 & $\begin{array}{l}\text { Dipodomys deserti (desert } \\
\text { kangaroo rat) }\end{array}$ & Heteromyidae & 7.21 & & .105 & $\mathrm{D}$ & Lawler and Geluso 1986 \\
\hline $\mathrm{Dm}$ & 51 & $\begin{array}{l}\text { Dipodomys merriami } \\
\quad \text { (Merriam's kangaroo rat) }\end{array}$ & Heteromyidae & 8.5 & .4534 & .0367 & $\mathrm{D}$ & $\begin{array}{l}\text { Sperber 1944; Carpenter 1966; } \\
\text { Munkacsi and Palkovits } \\
\text { 1977; Altschuler et al. } 1979\end{array}$ \\
\hline Do & 52 & $\begin{array}{l}\text { Dipodomys ordii (Ord's } \\
\text { kangaroo rat) }\end{array}$ & Heteromyidae & 8.2 & & .044 & $\mathrm{D}$ & Lawler and Geluso 1986 \\
\hline Ds & 53 & $\begin{array}{l}\text { Dipodomys spectabilis } \\
\text { (banner-tailed kangaroo } \\
\text { rat) }\end{array}$ & Heteromyidae & 8.5 & & .1 & $\mathrm{D}$ & $\begin{array}{l}\text { Schmidt-Nielsen et al. 1948; } \\
\text { Munkacsi and Palkovits } \\
1977\end{array}$ \\
\hline DA & 54 & Dipodomys agilis & Heteromyidae & 8 & & .0543 & $\mathrm{D}$ & $\begin{array}{l}\text { Sperber 1944; Price and } \\
\text { Longland } 1989\end{array}$ \\
\hline $\mathrm{DM}$ & 55 & Dipodomys microps & Heteromyidae & 8.61 & .75 & .062 & $\mathrm{D}$ & $\begin{array}{l}\text { Breyen et al. 1973; Ojeda et al. } \\
1999\end{array}$ \\
\hline
\end{tabular}




\begin{tabular}{|c|c|c|c|c|c|c|c|c|}
\hline $\begin{array}{l}\text { Tip } \\
\text { Code }\end{array}$ & $\begin{array}{l}\text { Tip } \\
\text { No. }\end{array}$ & $\begin{array}{l}\text { Genus and Species } \\
\text { (Common Name) }\end{array}$ & Family & RMT & $\begin{array}{l}\text { Kidney } \\
\text { Mass } \\
(\mathrm{g})\end{array}$ & $\begin{array}{l}\text { Body } \\
\text { Mass } \\
(\mathrm{kg})\end{array}$ & Habitat & Reference \\
\hline Cf & 56 & $\begin{array}{l}\text { Chaetodipus formousus (long- } \\
\text { tailed pocket mouse) }\end{array}$ & Heteromyidae & 9.68 & & .0179 & $\mathrm{D}$ & Lawler and Geluso 1986 \\
\hline $\mathrm{CP}$ & 57 & $\begin{array}{l}\text { Chaetodipus penicillatus } \\
\text { (desert pocket mouse) }\end{array}$ & Heteromyidae & 17.6 & .1886 & .0159 & $\mathrm{D}$ & $\begin{array}{l}\text { Munkacsi and Palkovits 1977; } \\
\text { Altschuler et al. 1979; } \\
\text { Beuchat } 1996\end{array}$ \\
\hline $\mathrm{Cb}$ & 58 & $\begin{array}{l}\text { Chaetodipus baileyi (Bailey's } \\
\text { pocket mouse) }\end{array}$ & Heteromyidae & & .2352 & .0257 & $\mathrm{D}$ & Altschuler et al. 1979 \\
\hline $\mathrm{Pa}$ & 59 & $\begin{array}{l}\text { Perognathus amplus (Arizona } \\
\text { pocket mouse) }\end{array}$ & Heteromyidae & & .1338 & .0058 & $\mathrm{D}$ & Altschuler et al. 1979 \\
\hline $\mathrm{Pl}$ & 60 & $\begin{array}{l}\text { Perognathus longimembris } \\
\quad \text { (little pocket mouse) }\end{array}$ & Heteromyidae & 11.6 & & .009 & $\mathrm{D}$ & Beuchat 1996 \\
\hline $\mathrm{Zh}$ & 61 & $\begin{array}{l}\text { Zapus hudsonius (meadow } \\
\text { jumping mouse) }\end{array}$ & Zapodidae & & .218 & .0193 & M & Quiring 1950 \\
\hline $\mathrm{Jj}$ & 62 & Jaculus jaculus (jerboa) & Dipodidae & 9.3 & .41 & .042 & $\mathrm{D}$ & $\begin{array}{l}\text { Sperber 1944; Schmidt-Nielsen } \\
\text { et al. 1948; Munkacsi and } \\
\text { Palkovits } 1965\end{array}$ \\
\hline $\mathrm{Ne}$ & 63 & $\begin{array}{l}\text { Neotomys ebriosus (Chile; 2, } \\
\text { 0) }\end{array}$ & Muridae & 6.3 & .20 & .062 & M & This study (C.Z.) \\
\hline $\mathrm{Ol}$ & 64 & $\begin{array}{l}\text { Oligoryzomys longicaudatus } \\
\quad(\text { Chile; } 5,4)\end{array}$ & Muridae & 6.8 & .20 & .029 & M & This study (C.Z.) \\
\hline $\mathrm{Ax}$ & 65 & $\begin{array}{l}\text { Abrothrix xanthorhinus } \\
\quad(\text { Chile; } 4,1)\end{array}$ & Muridae & 7.9 & .30 & .022 & M & This study (C.Z.) \\
\hline $\mathrm{Al}$ & 66 & $\begin{array}{l}\text { Abrothrix longipilis (Chile; } 6 \text {, } \\
\text { 3) }\end{array}$ & Muridae & 7.1 & .46 & .025 & M & This study (C.Z.) \\
\hline Ao & 67 & $\begin{array}{l}\text { Abrothrix olivaceus (Chile; } 3 \text {, } \\
\text { 4) }\end{array}$ & Muridae & 8.0 & .22 & .018 & $\mathrm{D}$ & This study (C.Z.) \\
\hline $\mathrm{Aa}$ & 68 & $\begin{array}{l}\text { Abrothrix andinus (Chile; } 4 \text {, } \\
\text { 2) }\end{array}$ & Muridae & 7.6 & .18 & .022 & $\mathrm{D}$ & This study (C.Z.) \\
\hline aa & 69 & A. andinus (Argentina; 6, 3) & Muridae & 8.1 & .22 & .017 & $\mathrm{D}$ & This study (E.C.-V. and C.Z.) \\
\hline $\mathrm{CM}$ & 70 & $\begin{array}{l}\text { Chelemys macronyx (Chile; } 4 \text {, } \\
\text { 1) }\end{array}$ & Muridae & 5.8 & .58 & .049 & M & This study (C.Z.) \\
\hline $\mathrm{Bl}$ & 71 & $\begin{array}{l}\text { Bolomys lactens (Argentina; } \\
\quad 2,0)\end{array}$ & Muridae & 7.1 & .28 & .036 & $\mathrm{SD}$ & This study (E.C.-V. and C.Z.) \\
\hline $\mathrm{Av}$ & 72 & $\begin{array}{l}\text { Akodon varius (Argentina; } 5 \text {, } \\
\text { 2) }\end{array}$ & Muridae & 7.5 & .18 & .033 & SD & This study (E.C.-V. and C.Z.) \\
\hline $\mathrm{AB}$ & 73 & $\begin{array}{l}\text { Akodon berlepschii (Chile; } 3 \text {, } \\
\text { 1) }\end{array}$ & Muridae & 7.8 & .32 & .018 & $\mathrm{D}$ & This study (C.Z.) \\
\hline AA & 74 & $\begin{array}{l}\text { Akodon albiventer (Chile; } 1 \text {, } \\
\text { 4) }\end{array}$ & Muridae & 7.6 & .34 & .022 & $\mathrm{D}$ & This study (C.Z.) \\
\hline $\mathrm{aA}$ & 75 & $\begin{array}{l}\text { A. albiventer (Argentina; } 4 \text {, } \\
\text { 4) }\end{array}$ & Muridae & 7.3 & .32 & .023 & SD & This study (E.C.-V. and C.Z.) \\
\hline am & 76 & Akodon molinae & Muridae & 10.09 & & .03111 & $\mathrm{D}$ & Diaz and Ojeda 1999 \\
\hline $\mathrm{cc}$ & 77 & $\begin{array}{l}\text { Calomys callosus (Argentina; } \\
\quad 8,1 \text { ) }\end{array}$ & Muridae & 6.8 & .24 & .016 & $\mathrm{SD}$ & This study (E.C.-V. and C.Z.) \\
\hline CL & 78 & Calomys lepidus (Chile; 4, 0) & Muridae & 6.2 & .26 & .014 & M & This study (C.Z.) \\
\hline $\mathrm{Cm}$ & 79 & Calomys musculinus & Muridae & 12.29 & & .01273 & $\mathrm{D}$ & Diaz and Ojeda 1999 \\
\hline $\mathrm{cm}$ & 80 & $\begin{array}{l}\text { C. musculinus (Argentina; } 5 \text {, } \\
\text { 3) }\end{array}$ & Muridae & 7.2 & .26 & .015 & SD & This study (E.C.-V. and C.Z.) \\
\hline Ep & 81 & $\begin{array}{l}\text { Eligmodontia puerulus (Chile; } \\
\quad 3,1)\end{array}$ & Muridae & 8.0 & .18 & .018 & $\mathrm{D}$ & This study (C.Z.) \\
\hline ET & 82 & $\begin{array}{l}\text { Eligmodontia typus } \\
\quad(\text { Argentina; } 7,2)\end{array}$ & Muridae & 7.8 & .18 & .016 & SD & This study (E.C.-V. and C.Z.) \\
\hline
\end{tabular}




\begin{tabular}{|c|c|c|c|c|c|c|c|c|}
\hline $\begin{array}{l}\text { Tip } \\
\text { Code }\end{array}$ & $\begin{array}{l}\text { Tip } \\
\text { No. }\end{array}$ & $\begin{array}{l}\text { Genus and Species } \\
\text { (Common Name) }\end{array}$ & Family & RMT & $\begin{array}{l}\text { Kidney } \\
\text { Mass } \\
\text { (g) }\end{array}$ & $\begin{array}{l}\text { Body } \\
\text { Mass } \\
(\mathrm{kg})\end{array}$ & Habitat & Reference \\
\hline Et & 83 & E. typus & Muridae & 11.42 & & .01858 & $\mathrm{D}$ & Diaz and Ojeda 1999 \\
\hline em & 84 & Eligmodontia moreni & Muridae & 10.66 & & .0145 & $\mathrm{D}$ & Diaz and Ojeda 1999 \\
\hline Eh & 85 & $\begin{array}{l}\text { Eligmodontia hirtipes (Chile; } \\
\quad 3,1 \text { ) }\end{array}$ & Muridae & 9.0 & .18 & .017 & $\mathrm{D}$ & This study (C.Z.) \\
\hline EM & 86 & $\begin{array}{l}\text { Eligmodontia marica } \\
\quad(\text { Argentina; } 3,0)\end{array}$ & Muridae & 7.5 & .24 & .017 & SD & This study (E.C.-V. and C.Z.) \\
\hline$S d$ & 87 & Salinomys delicatus & Muridae & 13.98 & & .0125 & $\mathrm{D}$ & Diaz and Ojeda 1999 \\
\hline ar & 88 & Andalgalomys roigi & Muridae & 12.6 & & .028 & $\mathrm{D}$ & Diaz and Ojeda 1999 \\
\hline $\mathrm{a} 2$ & 89 & A. roigi (Argentina; 4,1$)$ & Muridae & 8.2 & .26 & .029 & $\mathrm{SD}$ & This study (E.C.-V. and C.Z.) \\
\hline $\mathrm{AO}$ & 90 & Andalgalomys olrogi & Muridae & 13.48 & & .023 & $\mathrm{D}$ & Diaz and Ojeda 1999 \\
\hline gg & 91 & Graomys griseoflavus & Muridae & 9.64 & & .0545 & $\mathrm{D}$ & Diaz and Ojeda 1999 \\
\hline GG & 92 & $\begin{array}{l}\text { G. griseoflavus (Argentina; 6, } \\
\text { 3) }\end{array}$ & Muridae & 7.1 & .966 & .056 & $\mathrm{SD}$ & This study (E.C.-V. and C.Z.) \\
\hline GD & 93 & $\begin{array}{r}\text { Graomys domorum } \\
\quad(\text { Argentina; } 3,1)\end{array}$ & Muridae & 6.7 & .88 & .082 & $\mathrm{D}$ & This study (E.C.-V. and C.Z.) \\
\hline $\mathrm{Ae}$ & 94 & $\begin{array}{l}\text { Andinomys edax (Argentina; } \\
2,1)\end{array}$ & Muridae & 6.4 & .38 & .065 & $\mathrm{D}$ & This study (E.C.-V. and C.Z.) \\
\hline $1 \mathrm{P}$ & 95 & $\begin{array}{l}\text { Loxodontomys pikumche } \\
\quad \text { (Chile; } 4,2)\end{array}$ & Muridae & 5.2 & .52 & .043 & M & This study (C.Z.) \\
\hline aS & 96 & $\begin{array}{l}\text { Auliscomys sublimis (Chile; } 3 \text {, } \\
\text { 1) }\end{array}$ & Muridae & 7.1 & .28 & .036 & $\mathrm{D}$ & This study (C.Z.) \\
\hline $\mathrm{Ab}$ & 97 & $\begin{array}{l}\text { Auliscomys boliviensis (Chile; } \\
\quad 6,3)\end{array}$ & Muridae & 7.0 & .50 & .033 & $\mathrm{D}$ & This study (C.Z.) \\
\hline $\mathrm{PO}$ & 98 & $\begin{array}{l}\text { Phyllotis osilae (Argentina; } 3 \text {, } \\
\text { 2) }\end{array}$ & Muridae & 6.7 & .22 & .053 & SD & This study (E.C.-V. and C.Z.) \\
\hline pO & 99 & Phyllotis osgoodi (Chile; 4,2$)$ & Muridae & 7.0 & .38 & .064 & $\mathrm{D}$ & This study (C.Z.) \\
\hline $\mathrm{Pv}$ & 100 & $\begin{array}{l}\text { Phyllotis xanthopygus } \\
\quad \text { vaccarum (Chile; } 2,4)\end{array}$ & Muridae & 7.6 & 1.22 & .082 & $\mathrm{D}$ & This study (C.Z.) \\
\hline Px & 101 & Phyllotis xanthopygus & Muridae & 10.1 & & .044 & $\mathrm{D}$ & Diaz and Ojeda 1999 \\
\hline PX & 102 & $\begin{array}{l}\text { P. xanthopygus (Argentina; } 7 \text {, } \\
\text { 2) }\end{array}$ & Muridae & 7.3 & .34 & .034 & $\mathrm{D}$ & This study (E.C.-V. and C.Z.) \\
\hline $\mathrm{pC}$ & 103 & $\begin{array}{l}\text { Phyllotis chilensis (Chile; } 3 \text {, } \\
\text { 1) }\end{array}$ & Muridae & 9.2 & .26 & .027 & $\mathrm{D}$ & This study (C.Z.) \\
\hline $\mathrm{pR}$ & 104 & $\begin{array}{l}\text { Phyllotis rupestris (Chile; } 5 \text {, } \\
\text { 2) }\end{array}$ & Muridae & 7.6 & .28 & .036 & $\mathrm{D}$ & This study (C.Z.) \\
\hline $\mathrm{pM}$ & 105 & $\begin{array}{l}\text { Phyllotis magister (Chile; } 3 \text {, } \\
\text { 1) }\end{array}$ & Muridae & 7.3 & .92 & .113 & $\mathrm{D}$ & This study (C.Z.) \\
\hline $\mathrm{Pd}$ & 106 & Phyllotis darwini (Chile; 5, 4) & Muridae & 6.4 & .42 & .06 & $\mathrm{D}$ & This study (C.Z.) \\
\hline $\mathrm{Nm}$ & 107 & Neotoma mexicana & Muridae & 6.3 & & .098 & SD & Brownfield and Wunder 1976 \\
\hline N2 & 108 & Neotoma albigula & Muridae & 6.56 & & .095 & SD & MacMillen and Lee 1967 \\
\hline OT & 109 & Onychomys torridus & Muridae & & .3306 & .0219 & $\mathrm{D}$ & Altschuler et al. 1979 \\
\hline P4 & 110 & $\begin{array}{l}\text { Peromyscus leucopus (field- } \\
\text { caught adult in South } \\
\text { Dakota) }\end{array}$ & Muridae & 7.3 & .120 & .0298 & SD & $\begin{array}{l}\text { Oswald 1998, and personal } \\
\text { communication for body } \\
\text { mass }\end{array}$ \\
\hline P3 & 111 & $\begin{array}{l}\text { P. leucopus (field-caught } \\
\text { adult in Pennsylvania) }\end{array}$ & Muridae & 7.28 & .117 & .0268 & M & $\begin{array}{l}\text { Oswald 1998, and personal } \\
\text { communication for body } \\
\text { mass }\end{array}$ \\
\hline PL & 112 & P. leucopus (New York) & Muridae & 6.5 & & .0218 & M & $\begin{array}{l}\text { Heisinger et al. 1973; Deavers } \\
\text { and Hudson } 1979\end{array}$ \\
\hline $\mathrm{Pe}$ & 113 & $\begin{array}{l}\text { Peromyscus eremicus (cactus } \\
\text { mouse) }\end{array}$ & Muridae & & .4454 & .0228 & $\mathrm{D}$ & Altschuler et al. 1979 \\
\hline
\end{tabular}




\begin{tabular}{|c|c|c|c|c|c|c|c|c|}
\hline $\begin{array}{l}\text { Tip } \\
\text { Code }\end{array}$ & $\begin{array}{l}\text { Tip } \\
\text { No. }\end{array}$ & $\begin{array}{l}\text { Genus and Species } \\
\text { (Common Name) }\end{array}$ & Family & RMT & $\begin{array}{l}\text { Kidney } \\
\text { Mass } \\
\text { (g) }\end{array}$ & $\begin{array}{l}\text { Body } \\
\text { Mass } \\
(\mathrm{kg})\end{array}$ & Habitat & Reference \\
\hline Dg & 114 & $\begin{array}{l}\text { Dicrostonyx groenlandicus } \\
\quad \text { (collared lemming) }\end{array}$ & Muridae & & .481 & .0552 & M & Quiring 1950 \\
\hline $\mathrm{Na}$ & 115 & $\begin{array}{l}\text { Neofiber alleni (round-tailed } \\
\text { muskrat) }\end{array}$ & Muridae & 3.6 & & .25 & A & Pfeiffer 1970; Sperber 1944 \\
\hline $\mathrm{OZ}$ & 116 & Ondatra zibethicus (muskrat) & Muridae & & 7.45 & .9 & A & Quiring 1950 \\
\hline $\mathrm{Cg}$ & 117 & $\begin{array}{l}\text { Clethrionomys gapperi } \\
\text { (southern red-backed } \\
\text { vole) }\end{array}$ & Muridae & 4.3 & & .0248 & M & Deavers and Hudson 1979 \\
\hline MA & 118 & Microtus agrestis (field vole) & Muridae & 5.8 & .48 & .03 & M & Sperber 1944 \\
\hline $\mathrm{Me}$ & 119 & $\begin{array}{l}\text { Microtus pennsylvanicus } \\
\quad(=\text { drummondi })\end{array}$ & Muridae & 6.1 & & .038 & M & Beuchat 1996 \\
\hline MP & 120 & $\begin{array}{l}\text { Microtus pennsyvanicus } \\
\text { pennsylvanicus }\end{array}$ & Muridae & & .31145 & .02655 & M & $\begin{array}{l}\text { Heisinger et al. 1973; Quiring } \\
1950\end{array}$ \\
\hline $\mathrm{Mz}$ & 121 & $\begin{array}{l}\text { Mesocricetus auratus (golden } \\
\text { hamster) }\end{array}$ & Muridae & & .636 & .12 & $\mathrm{SD}$ & Spector 1956 \\
\hline $\mathrm{mA}$ & 122 & M. auratus & Muridae & 8.6 & .61 & .0593 & $\mathrm{SD}$ & $\begin{array}{l}\text { Brosh } 1971 \text {, as translated by } \\
\text { G. Perry (personal } \\
\text { communication) }\end{array}$ \\
\hline $\mathrm{Ma}$ & 123 & M. auratus & Muridae & 8.01 & & .105 & $\mathrm{SD}$ & $\begin{array}{l}\text { Munkacsi and Palkovits 1977; } \\
\text { Trojan 1977, } 1979\end{array}$ \\
\hline $\mathrm{Cr}$ & 124 & $\begin{array}{l}\text { Cricetus cricetus (common } \\
\text { hamster) }\end{array}$ & Muridae & 5.69 & .996 & .108 & M & $\begin{array}{l}\text { Quiring 1950; Sperber 1944; } \\
\text { Trojan 1977, } 1979\end{array}$ \\
\hline Gs & 125 & Gerbillurus setzeri & Muridae & 8.35 & & .028 & $\mathrm{D}$ & $\begin{array}{l}\text { Downs and Perrin 1991; Frean } \\
\text { et al. } 1998\end{array}$ \\
\hline G2 & 126 & Gerbillurus paeba & Muridae & 5.97 & & .029 & $\mathrm{D}$ & $\begin{array}{l}\text { Downs and Perrin 1991; Frean } \\
\text { et al. } 1998\end{array}$ \\
\hline sc & 127 & $\begin{array}{l}\text { Skeetamys calurus (bushy- } \\
\text { tailed jiird) }\end{array}$ & Muridae & 9.03 & .456 & .0577 & $\mathrm{D}$ & $\begin{array}{l}\text { Brosh } 1971 \text {, as translated by } \\
\text { G. Perry (personal } \\
\text { communication) }\end{array}$ \\
\hline $\mathrm{Mh}$ & 128 & $\begin{array}{l}\text { Meriones hurrianae (Indian } \\
\text { desert gerbil) }\end{array}$ & Muridae & 12.6 & & .062 & $\mathrm{D}$ & $\begin{array}{l}\text { Purohit 1975; Goyal et al. } \\
\quad 1988\end{array}$ \\
\hline Ms & 129 & Meriones shawi & Muridae & & .627 & .1707 & $\mathrm{D}$ & Rabhi et al. 1996 \\
\hline MT & 130 & Meriones tristrami (jird) & Muridae & 8.2 & .378 & .0551 & $\mathrm{D}$ & $\begin{array}{l}\text { Brosh } 1971 \text {, as translated by } \\
\text { G. Perry (personal } \\
\text { communication); see also } \\
\text { Borut and Shkolnik } 1974\end{array}$ \\
\hline $\mathrm{Mu}$ & 131 & $\begin{array}{l}\text { Meriones unguiculatus (mean } \\
\text { of sexes) }\end{array}$ & Muridae & & 1.01 & .094 & $\mathrm{D}$ & Kramer 1964 \\
\hline MU & 132 & $\begin{array}{l}\text { M. unguiculatus (Mongolian } \\
\text { gerbil) }\end{array}$ & Muridae & 7.51 & & .07 & $\mathrm{D}$ & $\begin{array}{l}\text { Munkacsi and Palkovits 1977; } \\
\text { Edwards et al. } 1983\end{array}$ \\
\hline MC & 133 & Meriones crassus (jird) & Muridae & 10.34 & .46 & .0671 & $\mathrm{D}$ & $\begin{array}{l}\text { Brosh 1971, as translated by } \\
\text { G. Perry (personal } \\
\text { communication) }\end{array}$ \\
\hline Po & 134 & $\begin{array}{l}\text { Psammomys obesus (sand } \\
\quad \text { rat) }\end{array}$ & Muridae & 10.7 & & .15 & $\mathrm{D}$ & $\begin{array}{l}\text { Sperber 1944; Schmidt-Nielsen } \\
1964\end{array}$ \\
\hline Gd & 135 & Gerbillus dasyurus & Muridae & 9.97 & .176 & .028 & $\mathrm{D}$ & $\begin{array}{l}\text { Brosh } 1971 \text {, as translated by } \\
\text { G. Perry (personal } \\
\text { communication) }\end{array}$ \\
\hline G3 & 136 & Gerbillus gerbillus & Muridae & 10.17 & .152 & .0215 & $\mathrm{D}$ & $\begin{array}{l}\text { Brosh } 1971 \text {, as translated by } \\
\text { G. Perry (personal } \\
\text { communication) }\end{array}$ \\
\hline
\end{tabular}




\begin{tabular}{|c|c|c|c|c|c|c|c|c|}
\hline $\begin{array}{l}\text { Tip } \\
\text { Code }\end{array}$ & $\begin{array}{l}\text { Tip } \\
\text { No. }\end{array}$ & $\begin{array}{l}\text { Genus and Species } \\
\text { (Common Name) }\end{array}$ & Family & RMT & $\begin{array}{l}\text { Kidney } \\
\text { Mass } \\
\text { (g) }\end{array}$ & $\begin{array}{l}\text { Body } \\
\text { Mass } \\
(\mathrm{kg})\end{array}$ & Habitat & Reference \\
\hline $\mathrm{Gg}$ & 137 & $\begin{array}{l}\text { G. gerbillus (northern pygmy } \\
\text { gerbil) }\end{array}$ & Muridae & 10.5 & .396 & .044 & $\mathrm{D}$ & $\begin{array}{l}\text { Sperber 1944; Burns 1956; } \\
\text { Khalil and Tawfic 1963; } \\
\text { Schmidt-Nielsen } 1964\end{array}$ \\
\hline $\mathrm{RN}$ & 138 & $\begin{array}{l}\text { Rattus norvegicus (Chile; 5, } \\
\text { 4) }\end{array}$ & Muridae & 6.5 & 1.78 & .17 & M & This study (C.Z.) \\
\hline $\mathrm{Rr}$ & 139 & $\begin{array}{l}\text { Rattus rattus (wild-caught } \\
\quad \text { rat) }\end{array}$ & Muridae & 5.8 & & .172 & M & Sperber 1944; Collins 1978 \\
\hline $\mathrm{Hc}$ & 140 & $\begin{array}{l}\text { Hydromys chrysogaster (water } \\
\quad \text { rat) }\end{array}$ & Muridae & 3.9 & & .85 & A & Sperber 1944 \\
\hline $\mathrm{Mg}$ & 141 & $\begin{array}{l}\text { Mesembriomys gouldii } \\
\text { (shaggy rabbit-rat) }\end{array}$ & Muridae & 8 & & .65 & $\mathrm{D}$ & Purohit $1974 b$ \\
\hline NA & 142 & $\begin{array}{l}\text { Notomys alexis (Australian } \\
\text { hopping mouse) }\end{array}$ & Muridae & 7.9 & .336 & .029 & $\mathrm{D}$ & $\begin{array}{l}\text { Hewitt 1981; MacMillen and } \\
\text { Lee 1967, 1969; Purohit } \\
1974 a\end{array}$ \\
\hline $\mathrm{Ph}$ & 143 & $\begin{array}{l}\text { Pseudomys (= Leggadina) } \\
\text { hermannsburgensis }\end{array}$ & Muridae & 7.5 & & .0126 & $\mathrm{D}$ & $\begin{array}{l}\text { MacMillen and Lee 1967; } \\
\text { MacMillen et al. 1972; } \\
\text { Purohit } 1974 a\end{array}$ \\
\hline $\mathrm{PD}$ & 144 & $\begin{array}{l}\text { Pseudomys (= Leggadina) } \\
\quad \text { delicatula }\end{array}$ & Muridae & 7.7 & & .012 & $\mathrm{D}$ & Purohit $1974 a, 1974 b$ \\
\hline $\mathrm{aM}$ & 145 & Apodemus mystacinus & Muridae & 6.38 & .25 & .0364 & $\mathrm{SD}$ & $\begin{array}{l}\text { Brosh 1971, as translated by } \\
\text { G. Perry (personal } \\
\text { communication); see also } \\
\text { Borut and Shkolnik 1974; } \\
\text { Shkolnik } 1988\end{array}$ \\
\hline M4 & 146 & Mus musculus (Chile; 3, 1) & Muridae & 6.6 & .08 & .012 & M & This study (C.Z.) \\
\hline $\mathrm{Mm}$ & 147 & $\begin{array}{l}\text { M. musculus (house mouse, } \\
\text { assumed to be wild) }\end{array}$ & Muridae & 8 & & .018 & M & Sperber 1944 \\
\hline M2 & 148 & $\begin{array}{l}\text { Mus domesticus (Caithness } \\
\text { British Mainland; smallest } \\
\text { body mass reported) }\end{array}$ & Muridae & & .1758 & .0119 & M & Berry and Jakobson 1975 \\
\hline M1 & 149 & $\begin{array}{l}\text { M. domesticus (Faray Orkney } \\
\text { Island; largest body mass } \\
\text { reported) }\end{array}$ & Muridae & & .4791 & .0262 & $\mathrm{M}$ & Berry and Jakobson 1975 \\
\hline $\operatorname{Tn}$ & 150 & Thallamys nigricauda & Muridae & 5.67 & & .082 & $\mathrm{D}$ & Frean et al. 1998 \\
\hline AN & 151 & Arvicanthis niloticus & Muridae & & 1.3 & .122 & $\mathrm{SD}$ & This study (M.A.A.) \\
\hline $\mathrm{Oa}$ & 152 & Otomys angoniensis & Muridae & 4.06 & 1.21 & .1158 & M & $\begin{array}{l}\text { Pillay et al. 1994, and personal } \\
\text { communication }\end{array}$ \\
\hline Os & 153 & Otomys sloggetti robertsi & Muridae & 4.3 & .96 & .1023 & M & $\begin{array}{l}\text { Pillay et al. 1994, and personal } \\
\text { communication }\end{array}$ \\
\hline Oi & 154 & Otomys irroratus & Muridae & 3.39 & 1.76 & .1723 & M & $\begin{array}{l}\text { Pillay et al. 1994, and personal } \\
\text { communication }\end{array}$ \\
\hline $\mathrm{Ou}$ & 155 & Otomys unisulcatus & Muridae & 5.99 & 1.88 & .1176 & $\mathrm{D}$ & $\begin{array}{l}\text { Pillay et al. 1994, and personal } \\
\text { communication }\end{array}$ \\
\hline $\mathrm{pL}$ & 156 & Parotomys littledalei & Muridae & 6.79 & 3 & .107 & $\mathrm{D}$ & $\begin{array}{l}\text { Pillay et al. 1994, and personal } \\
\text { communication }\end{array}$ \\
\hline $\mathrm{Pb}$ & 157 & Parotomys brantsii & Muridae & 5.81 & 1.75 & .112 & $\mathrm{D}$ & $\begin{array}{l}\text { Pillay et al. 1994, and personal } \\
\text { communication }\end{array}$ \\
\hline PC & 158 & $\begin{array}{l}\text { Praomys ( = Mastomys) } \\
\text { coucha microdon }\end{array}$ & Muridae & & .265 & .0218 & M & Quiring 1950 \\
\hline A5 & 159 & $\begin{array}{l}\text { Acomys cahirinus (north } \\
\text { Israel) }\end{array}$ & Muridae & 8.31 & .189 & .0366 & SD & $\begin{array}{l}\text { Brosh } 1971 \text {, as translated by } \\
\text { G. Perry (personal } \\
\text { communication) }\end{array}$ \\
\hline
\end{tabular}


Table A1 (Continued)

\begin{tabular}{|c|c|c|c|c|c|c|c|c|}
\hline $\begin{array}{l}\text { Tip } \\
\text { Code }\end{array}$ & $\begin{array}{l}\text { Tip } \\
\text { No. }\end{array}$ & $\begin{array}{l}\text { Genus and Species } \\
\text { (Common Name) }\end{array}$ & Family & RMT & $\begin{array}{l}\text { Kidney } \\
\text { Mass } \\
(\mathrm{g})\end{array}$ & $\begin{array}{l}\text { Body } \\
\text { Mass } \\
(\mathrm{kg})\end{array}$ & Habitat & Reference \\
\hline A4 & 160 & A. cahirinus (Sinai) & Muridae & 9.92 & .171 & .0329 & $\mathrm{D}$ & $\begin{array}{l}\text { Brosh 1971, as translated by } \\
\text { G. Perry (personal } \\
\text { communication) }\end{array}$ \\
\hline A3 & 161 & A. cahirinus (Kabri) & Muridae & 9.32 & & .0366 & SD & Weissenberg 1977 \\
\hline A2 & 162 & A. cahirinus (Eilat) & Muridae & 10.84 & & .0329 & $\mathrm{D}$ & Weissenberg 1977 \\
\hline Ac & 163 & A. cahirinus & Muridae & 9.4 & & .033 & $\mathrm{D}$ & $\begin{array}{l}\text { Purohit 1975; Haines and } \\
\text { Schmidt-Nielsen } 1977\end{array}$ \\
\hline $\mathrm{aR}$ & 164 & $\begin{array}{l}\text { Acomys russatus (spiny } \\
\text { mouse) }\end{array}$ & Muridae & 11.4 & .229 & .0528 & $\mathrm{D}$ & $\begin{array}{l}\text { Brosh } 1971 \text {, as translated by } \\
\text { G. Perry (personal } \\
\text { communication); see also } \\
\text { Borut and Shkolnik } 1974\end{array}$ \\
\hline
\end{tabular}

Note. For habitat, $\mathrm{A}=$ aquatic, $\mathrm{M}=$ mesic, $\mathrm{DM}=$ desert mesic (as used by Beuchat [1996]), $\mathrm{SD}=$ semidesert, and $\mathrm{D}=$ desert. For statistical analyses and figures, species listed as DM were pooled into the SD category. For species new to this study, sample sizes are listed in parentheses (male, female).

\section{Literature Cited}

Abrahams S., L. Greenwald, and D. Stetson. 1991. Contribution of renal medullary mitochondrial density to urine concentrating ability in mammals. Am J Physiol 261:R719-R726.

Al-kahtani M.A. 2003. Evolutionary and Phenotypic Plasticity of Mammalian Kidney: Using the Laboratory House Mouse as a Model. PhD diss. University of Wisconsin-Madison.

Altschuler E.M., R.B. Nagle, D.J. Braun. S.L. Lindstedt, and P.H. Krutzsch. 1979. Morphological study of the desert heteromyid kidney with emphasis on the genus Perognathus. Anat Rec 194:461-468.

Bakko E.B. 1975. Field water balance performance in prairie dogs (Sciurus carolinensis) and red squirrels (Tamiasciurus hudsonicus). Comp Biochem Physiol 51A:759-768.

Bankir L. and C. de Rouffignac. 1985. Urinary concentrating ability: insights from comparative anatomy. Am J Physiol 249:R643-R666.

Bankir L., C. Fischer, S. Fischer, K. Jukkala, H.C. Specht, and W. Kriz. 1988. Adaptation of the rat kidney to altered water intake and urine concentration. Pflueg Arch 412:42-53.

Baudinette R.V. 1974. The physiology of chronic water deprivation in the California ground squirrel (Spermophilus beecheyi): relevance to natural populations. J Zool (Lond) 173: 159-171.

Berry R.J. and M.E. Jakobson. 1975. Adaptation and adaptability in wild-living house mice (Mus musculus). J Zool (Lond) 176:391-402.

Beuchat C.A. 1990. Metabolism and the scaling of urine concentrating ability in mammals: resolution of a paradox? J Theor Biol 143:113-122.

- 1991. Body size, medullary thickness, and urine concentrating ability in mammals. Am J Physiol 258:R298-R308. - 1993. The scaling of concentrating ability in mammals. Pp. 259-279 in J.A. Brown, R.J. Balment, and J.C. Rankin, eds. New Insights in Vertebrate Kidney Function. Cambridge University Press, Cambridge.

1996. Structure and concentrating ability of the mammalian kidney: correlations with habitat. Am J Physiol 271: R157-R179.

Blake B.H. 1977. The effects of kidney structure and the annual cycle on water requirements in golden-mantled ground squirrels and chipmunks. Comp Biochem Physiol 58A:413419.

Blomberg S.P. and T. Garland, Jr. 2002. Tempo and mode in evolution: phylogenetic inertia, adaptation and comparative methods. J Evol Biol 15:899-910.

Blomberg S.P., T. Garland, Jr., and A.R. Ives. 2003. Testing for phylogenetic signal in comparative data: behavioral traits are more labile. Evolution 57:717-745.

Borut A. and A. Shkolnik. 1974. Physiological adaptations to the desert environment. Pp. 185-229 in D. Robertshaw, ed. Environmental Physiology. Vol. 7. University Park Press, Baltimore.

Braun J.E. 1998. Comparative renal function in reptiles, birds, and mammals. Pp. 62-71. Seminars in Avian and Exotic Pet Medicine. Vol. 7. Saunders, Philadelphia.

Breyen L.J., W.G. Bradley, and M.K. Yousef. 1973. Physiological and ecological studies on the chisel-toothed kangaroo rat, Dipodomys microps. Comp Biochem Physiol 44A:543-555.

Brosh A. 1971. Correlation between Kidney Structure and Urine Concentration Ability. Undergraduate thesis. Oranim College, Tivon, Israel.

Brownfield M.S. and B.A. Wunder. 1976. Relative medullary area: a new structural index for estimating urinary concentrating capacity of mammals. Comp Biochem Physiol 55A: 69-75.

Burns T.W. 1956. Endocrine factors in the water metabolism of the desert mammal. Gerbillus gerbillus. Endocrinology 58: 243-254. 
Butynski T.M. 1979. Body and organ growth of the springhare (Pedetes capensis). Acta Theriol 24:431-448.

Calder W.A. and E.L. Braun. 1983. Scaling of osmotic regulation in mammals and birds. Am J Physiol 244:R601-R606.

Carpenter R.E. 1966. A comparison of thermoregulation and water metabolism in the kangaroo rats Dipodomys agilis and Dipodomys merriami. Univ Calif Publ Zool 78:1-36.

Collins B.G. 1978. Water metabolism and the distribution of two species of Australian murids, Rattus rattus and Rattus villosissimus. Comp Biochem Physiol 61A:647-651.

Cook R.D. and S. Weisberg. 1999. Applied Regression Including Computing and Graphics. Wiley, New York.

Cortes A., M. Rosenmann, and C. Baez. 1990. Función del riñón y del pasaje nasal en la conservación de agua corporal en roedores simpátridos de Chile Central. Rev Chil Hist Nat 63: 279-291.

Cruz-Neto A.P., T. Garland, Jr., and A.S. Abe. 2001. Diet, phylogeny, and basal metabolic rate in phyllostomid bats. Zoology 104:49-58.

Dantzler W.H. and E.J. Braun. 1980. Comparative nephron function in reptiles, birds, and mammals. Am J Physiol 239: R197-R213.

Deavers D.R. and J.W. Hudson. 1979. Water metabolism and estimated field water budgets in two rodents (Clethrionomys gapperi and Peromyscus leucopus) and an insectivore (Blarina bervicauda) inhabiting the same mesic environment. Physiol Zool 52:137-152.

de Rouffignac C., L. Bankir, and N. Roinel. 1981. Renal function and concentrating ability in a desert rodent: the gundi (Ctenodactylus vali). Pflueg Arch 239:138-144.

Diaz G.B. and R.A. Ojeda. 1999. Kidney structure and allometry of Argentine desert rodents. J Arid Environ 41:453-461.

Dolph C.I., H.A. Braun, and E.W. Pfeiffer. 1962. The effect of vasopressin upon urine concentration in Aplodontia rufa (Sewellel) and the rabbit. Physiol Zool 35:263-269.

Downs C.T. and M.R. Perrin. 1991. Urinary concentrating ability of four Gerbillurus species of southern African arid regions. J Arid Environ 20:71-81.

Edwards B.A., K. Donaldson, and A.P. Simpson. 1983. Water balance and protein intake in the Mongolian gerbil (Meriones uniguiculatus). Comp Biochem Physiol 76A:807-815.

Eisenberg J.F. 1981. The Mammalian Radiations. University of Chicago Press, Chicago.

Felsenstein J. 1985. Phylogenies and the comparative method. Am Nat 125:1-15.

Folk G.E., Jr. 1974. Textbook of Environmental Physiology. 2d ed. Lea \& Febiger, Philadelphia.

Frean J., C.T. Downs, and B.G. Lovegrove. 1998. Osmoregulatory capacity of an arboreal rodent Thallomys nigricauda. J Arid Environ 40:97-107.

Freckleton R.P., P.H. Harvey, and M. Pagel. 2002. Phylogenetic analysis and comparative data: a test and review of evidence. Am Nat 160:712-726.
Garland T., Jr. 2001. Phylogenetic comparison and artificial selection: two approaches in evolutionary physiology. Pp. 107-132 in R.C. Roach, P.D. Wagner, and P.H. Hackett, eds. Hypoxia: From Genes to the Bedside. Advances in Experimental Biology and Medicine. Vol. 502. Kluwer Academic/ Plenum, New York.

Garland T., Jr., and S.C. Adolph. 1991. Physiological differentiation of vertebrate populations. Annu Rev Ecol Syst 22: 93-228.

- 1994. Why not to do two-species comparative studies: limitations on inferring adaptation. Physiol Zool 67:797-828.

Garland T., Jr., and R. Díaz-Uriarte. 1999. Polytomies and phylogenetically independent contrasts: an examination of the bounded degrees of freedom approach. Syst Biol 48:547-558.

Garland T., Jr., A.W. Dickerman, C. Janis, and J.A. Jones. 1993. Phylogenetic analysis of covariance by computer simulation. Syst Biol 42:265-292.

Garland T., Jr., P.H. Harvey, and A.R. Ives. 1992. Procedures for the analysis of comparative data using phylogenetically independent contrasts. Syst Biol 41:18-32.

Garland T., Jr., and A.R. Ives. 2000. Using the past to predict the present: confidence intervals for regression equations in phylogenetic comparative methods. Am Nat 155:346-364.

Garland T., Jr., P.E. Midford, and A.P. Ives. 1999. An introduction to phylogenetically based statistical methods, with a new method for confidence intervals on ancestral values. Am Zool 39:374-388.

Geluso K.N. 1978. Urine concentrating ability and renal structure of insectivorous bats. J Mammal 59:312-323.

Gottschalk W.C. 1987. History of the urinary concentrating mechanism. Kidney Int 31:507-511.

Goyal S.P., P.K. Ghosh, T.O. Sasidharan, and P. Chand. 1988. Body water relations in two species of gerbil (Tatera indica indica and Meriones hurrianae) of the Indian desert. J Comp Physiol 158B:127-134.

Grafen A. 1989. The phylogenetic regression. Biol Sci 326:119157.

Greegor D.H., Jr. 1975. Renal capabilities of an Argentine desert armadillo. J Mammal 56:626-632.

Greenwald L. 1989. The significance of renal relative medullary thickness. Physiol Zool 62:1005-1014.

Greenwald L. and D. Stetson. 1988. Urine concentration and the length of the renal papilla. News Physiol Sci 3:46-49.

Haines H. and B. Schmidt-Nielsen. 1977. Kidney function in spiny mice (Acomys cahirinus) acclimated to water restriction. Bull Mt Desert Isl Biol Lab 17:94-95.

Harlow H.J. and E.L. Braun. 1995. Kidney structure and function of obligate and facultative hibernators: the white-tailed prairie dog (Cynomys leucurus) and the black-tailed prairie dog (Cynomys ludovicianus). J Comp Physiol 165B:320-328.

Heisinger J.F. and S. Breitenbach. 1969. Renal structural characteristics as indexes of renal adaptation for water conservation in the genus Sylvilagus. Physiol Zool 42:160-172. 
Heisinger J.F., T.S. King, H.W. Halling, and B.L. Fields. 1973. Renal adaptation to macro- and micro-habitats in the family Cricetidae. Comp Biochem Physiol 44A:767-774.

Heller C.H. and T. Poulson. 1972. Altitudinal zonation of chipmunks (Eutamias): adaptations to aridity and high temperature. Am Midl Nat 87:296-313.

Hewitt S. 1981. Plasticity of renal function in the Australian desert rodent Notomys alexis. Comp Biochem Physiol 69A: 297-304.

Hickman G.C. and L.N. Brown. 1973. Pattern and rate of mound production in the southeastern pocket gopher (Geomys pinetis). J Mammal 54:971-975.

Huey R.B. and A.F. Bennett. 1990. Physiological adjustments to fluctuating thermal environments: an ecological and evolutionary perspective. Pp. 37-59 in R. Morimoto and A. Tissieres, eds. Stress Proteins in Biology and Medicine. Cold Spring Harbor Laboratory Press, Cold Spring, N.Y.

Hutcheon J.M., J.A.W. Kirsch, and T. Garland, Jr. 2002. A comparative analysis of brain size in relation to foraging ecology and phylogeny in the Chiroptera. Brain Behav Evol 60:165180.

Khalil F. and J. Tawfic. 1963. Some observations on the kidney of the desert Jaculus jaculus and Gerbillus gerbillus and their possible bearing on the water economy of these animals. J Exp Zool 154:259-271.

Kelt D.A., R.E. Palma, M.H. Gallardo, and J.A. Cook. 1991. Chromosomal multiformity in Eligmodontia (Muridae, Sigmodontinae), and verification of the status of Eligmodontia morgani. Z Säugetierkd 56:352-358.

Kramer A.W. 1964. Body and organ weights and linear measurements of the adult Mongolian gerbil. Anat Rec 150:343348.

Lawler R.M. and K.N. Geluso. 1986. Renal structure and body size in heteromyid rodents. J Mammal 67:367-372.

Layne J.N. 1954. The biology of the red squirrel, Tamiasciurus hudsonicus loquax (Bangs), in central New York. Ecol Monogr 24:227-267.

Leroi A.M., M.R. Rose, and G.V. Lauder. 1994. What does the comparative method reveal about adaptation? Am Nat 143: 381-402.

MacMillen R.E., R.V. Baudinette, and A.K. Lee. 1972. Water economy and energy metabolism of the sand inland mouse Leggadina hermannsburgensis. J Mammal 53:529-539.

MacMillen R.E. and T. Garland, Jr. 1989. Adaptive physiology. Pp. 143-168 in J.N. Lane and G.L. Kirkland, Jr., eds. Advances in the Study of Peromyscus (Rodentia). Texas Tech University Press, Lubbock.

MacMillen R.E. and D.S. Hinds. 1983. Water regulatory efficiency in heteromyid rodents: a model and its application. Ecology 64:152-164.

MacMillen R.E. and A.K. Lee. 1967. Australian desert mice: independence of exogenous water. Science 158:383-385.
1969. Water metabolism of Australian hopping mice. Comp Biochem Physiol 28:493-514.

Mares M.A., R.A. Ojeda, and R .M. Barquez. 1989. Guide to the Mammals of Salta Province, Argentina. University of Oklahoma Press, Norman.

Mares M.A., R.A. Ojeda, J.K. Braun, and R.M. Barquez. 1997. Systematics, distribution, and ecology of the mammals of Catamarca Province, Argentina. Pp. 89-154 in T.L. Yates, W.L. Gannon, and D.E. Wilson, eds. Life among the Muses: Papers in Honor of James S. Findley. Museum of Southwestern Biology, University of New Mexico, Albuquerque.

Marsh A.C., G. Louw, and H.H. Berry. 1978. Aspects of renal physiology nutrition and thermoregulation in the ground squirrel Xerus inauris. Madoqua 2:129-135.

Munkacsi I. and M. Palkovits. 1965. Volumetric analysis of glomerular size in kidneys of mammals living in desert, semidesert or water-rich environment in the Sudan. Circ Res 17: 303-311.

1977. Measurements on the kidneys and vasa recta of various mammals in relation to urine concentrating capacity. Acta Anat 98:456-468.

Musser G.M. and M.D. Carleton. 1993. Family Muridae. Pp. 501-756 in D.E. Wilson and D.M. Reeder, eds. Mammal Species of the World: A Taxonomic and Geographic Reference. $2 \mathrm{~d}$ ed. Smithsonian Institution, Washington, D.C.

Nungesser W.C. and E.W. Pfeiffer. 1965. Water balance and maximum concentrating capacity in the primitive rodent, Aplodontia rufa. Comp Biochem Physiol 14B:289-297.

Ojeda R.A., C.E. Borghi, G.B. Diaz, S.M. Giannoni, M.A. Mares, and J.K. Braun. 1999. Evolutionary convergence of the highly adapted desert rodent Tympanoctomys barrerae (Octodontidae). J Arid Environ 41:443-452.

Oswald C. 1998. Geographic variation and plasticity in renal function in the white-footed mouse, Peromyscus leucopus. J Mammal 79:1103-1110.

Pagel M.D. 1992. A method for the analysis of comparative data. J Theor Biol 156:431-442.

Pfeiffer E.W. 1970. Ecological and anatomical factors affecting the gradient of urea and non-urea solutes in mammalian kidneys. Pp. 358-365 in B. Schmidt-Nielsen and D.W.S. Kerr, eds. Urea and the Kidney. Excerpta Medica Foundation, Amsterdam.

Pillay N., K. Willan, and P.J. Taylor. 1994. Comparative renal morphology of some southern African otomyine rodents. Acta Theriol 39:37-48.

Price M.V. and W.S. Longland. 1989. Use of artificial seed patches by heteromyid rodents. J Mammal 70:316-322.

Purohit K.G. 1974a. Observation on histomorphology of kidneys and urine osmolarities in some Australian desert rodents. Zool Anz 193:221-227.

- 1974b. Observations on the role of kidney in survival of Tammar wallaby (Macropus eugenii, Marsupialia) on sea water. Z Angew Zool 61:495-506. 
1975. Histomorphology of kidney in the Indian desert gerbil, Meriones hurrianae and ecophysiological appraisal. Z Angew Zool 62:9-22.

Purohit K.G., C.P. Batra, and B.S. Gaur. 1973. Linear dimensions and relative medullary thickness in kidneys of some small Indian mammals. Indian J Zool 1:95-99.

Purohit K.G. and P.K. Ghosh. 1965. The organ : body weight relationships in the northern palm squirrel, Funambulus pennanti (Wroughton). Mammalia 29:35-41.

Purvis A. and T. Garland, Jr. 1993. Polytomies in comparative analysis of continuos characters. Syst Biol 42:569-573.

Quiring D.P. 1950. Functional Anatomy of the Vertebrates. McGraw-Hill, New York.

Rabhi M., M.V. Ugrumov, O.A. Goncharevskaya, W. Bengelloun, A. Calas, and Y.V. Natochin. 1996. Development of the hypothalamic vasopressin system and nephrons in Meriones shawi during ontogenesis. Anat Embryol 193:281-296.

Redford K.H. and J.F. Eisenberg. 1992. Mammals of the Neotropics. Vol. 2. The Southern Cone. University of Chicago Press, Chicago.

Reid I.A. and I.R. McDonald. 1968. Renal function in the marsupial, Trichosurus vulpecula. Comp Biochem Physiol 26B: 1071-1079.

Rezende E.L., F. Bozinovic, and T. Garland, Jr. 2004. Climatic adaptation and the evolution of basal and maximum rates of metabolism in rodents. Evolution 58:1361-1374.

Rezende E.L. and T. Garland, Jr. 2003. Comparaciones interespecíficas y métodos estadísticos filogenéticos. Pp. 79-98 in F. Bozinovic, ed. Fisiología Ecológica and Evolutiva. Teoría y casos de estudios en animales. Ediciones Universidad Católica de Chile, Santiago.

Rohlf F.J. 2001. Comparative methods for the analysis of continuous variables: geometric interpretations. Evolution 55: 2143-2160.

Schmid W.D. 1972. Nocturnalism and variance in ambient vapor pressure of water. Physiol Zool 45:302-309.

Schmidt-Nielsen B. and R. O'Dell. 1961. Structure and concentrating mechanism in the mammalian kidney. Am J Physiol 200:1119-1124.

Schmidt-Nielsen B., K. Schmidt-Nielsen, A. Brokaw, and H. Schneiderman. 1948. Water conservation in desert rodents. J Cell Comp Physiol 32:331-360.

Schmidt-Nielsen K. 1964. Desert Animals: Physiological Problems of Heat and Water. Oxford University Press, New York.

Shkolnik A.1988. Physiological adaptations to the environment: the Israeli experience. Pp. 487-496 in Y. Yom-Tov and E. Tchernov, eds. The Zoogeography of Israel. W. Junk, The Hague.
Silva M. and J.A. Downing. 1995. CRC Handbook of Mammalian Body Masses. CRC, Boca Raton, Fla.

Spector W.S. 1956. Handbook of Biological Data. Saunders, Philadelphia.

Sperber I. 1944. Studies on the mammalian kidney. Zool Bidr Upps 22:249-432.

Spotorno A.E., H. Cofre, G. Manriquez, Y. Vilina, P.A. Marquet, and L.I. Walter. 1998. A new species of Loxodontomys, another phyllotine mammal from the Andes of central Chile. Rev Chil Hist Nat 71:359-373.

Spotorno A.E., J. Sufan-Catalan, and L.I. Walker. 1994. Cytogenetics diversity and evolution of Andean species of Eligmodontia (Rodentia, Muridae). Z Säugetierkd 59:299-308.

Spotorno A.E., L.I. Walker, S.V. Flores, M. Yevennes, J.C. Marin, and C. Zuleta. 2000. Evolución de los filotinos (Rodentia, Muridae) en los Andes del Sur. Rev Chil Hist Nat 74:151166.

Spotorno A.E., C.A. Zuleta, and A. Cortés. 1990. Evolutionary systematics and heterocrony in Abrothrix species (Rodentia, Cricetidae). Evol Biol 4:37-62.

Tieleman B.I., J.B. Williams, and P. Bloomer. 2003. Adaptation of metabolism and evaporative water loss along an aridity gradient. Proc R Soc Lond B Biol Sci 270:207-214.

Trojan M. 1977. Water balance and renal adaptations in four Palaearctic hamsters. Naturwissenschaften 64:591-592.

- 1979. Comparative investigations on the water budget and the kidney function in the Palaearctic hamsters Cricetus cricetus (Leske, 1779), Mesocricetus auratus (Waterhouse, 1839), Cricetulus griseus (Milne-Edwards, 1867) and Phodopus sungorus (Pallas, 1770). Zool Jahrb Abt Allg Zool Physiol Tiere 83:192-223.

Vanhooydonck B. and R. Van Damme. 1999. Evolutionary relationships between body shape and habitat use in lacertid lizards. Evol Ecol Res 1:785-805.

Weissenberg S. 1977. Comparative Physiology in Two Populations of Common Spiny Mouse (Acomys cahirinus) from Desert and Mediterranean Regions. MSc thesis. Tel Aviv University. (Hebrew with English abstract.)

Weisser F., F.B. Lacy, H. Weber, and R.L. Jamison. 1970. Renal function in the chinchilla. Am J Physiol 219:1706-1713.

Wilson D.E. and D.M. Reeder, eds. 1993. Mammal Species of the World: A Taxonomic and Geographic Reference. $2 \mathrm{~d}$ ed. Smithsonian Institution, Washington, D.C.

Yaakobi D. and A. Shkolnik. 1974. Structure and concentrating capacity in kidneys of three species of hedgehogs. Am J Physiol 226:948-952. 


\section{Kidney Mass and Relative Medullary Thickness of Rodents in Relation to Habitat, Body Size, and Phylogeny}

Phylogenetic information was obtained from the literature. We attempted to consider all available molecular, morphological, and, in a few cases, paleontological information pertaining to the studied species. However, priority was always given to more recent trees constructed from biochemical or molecular data (e.g., DNA sequences). The monophyletic hypothesis of rodents has been supported by many cranioskeletal, dental, and soft anatomical characteristics (Carleton 1984; Luckett and Hartenberger 1985, 1993) as well as biochemical and molecular studies (Sarich 1985; Shoshani 1986; Czelusniak et al. 1990; Cao et al. 1994; Nedbal et al. 1994, 1996; Huchon et al. 1999, 2000). Analyses of a limited number of proteins led to questioning of rodent monophyly (Graur and Li 1991; D'Erchia et al. 1996), but those studies have been criticized for a lack of adequate sampling (Luckett and Hartenberger $\underline{1993}$ ) and on methodological grounds (Hasegawa et al. 1992).

Higher-Level Relationships

Nedbal et al. (1994, 1996) examined nucleotide sequence variation in the mitochondrial 12s ribosomal RNA (rRNA) gene for 59 species of mammals, including at least one representative for each of the families included in our data set. Their results showed that suborder Hystricognathi is monophyletic in origin and that suborder Sciurognathi is paraphyletic. They also found that the superfamilies Muroidea (Muridae) and Dipodoidea (Dipodiade) are a sister group of the superfamilies Geomyoidea (Heteromyidae + Geomyidae) and Pedetoidea (Pedetidae). Furthermore, they found strong support for the monophyletic origin for each of these families, which is in agreement with the morphological evidence (see, e.g., Luckett and Hartenberger 1985). We mainly follow Figure 6 of Nedbal et al. (1996). Nedbal et al. (1994) tested the phylogenetic relationships between the Caviomorpha of South America clade (Octodontoidea, Chinchillidae, Caviidae) and the African phiomorpha (Hystricidae). Their results showed that they are a sister group and that the Castiodea, Ctenodactyloidea, Aplodontoidea, and Sciuroidea are represented in one clade that makes a sister group with Hystricognathi rodents. Furthermore, the Octodontoidae is monophyletic and a sister group with Chinchillidae. The recent study of Huchon et al. (1999) supported the results of Nedbal et al. (1994, 1996). For the phylogenetic positions of families not included in those studies (Abrocomyidae, Octodontidae, Ctenomyidae), we consulted the Tree of Life web page (http://tolweb.org/tree/phylogeny.html).

Muridae

Most of the studied species belong to this family, which includes both Old and New World muroids. We used information from several primary sources (e.g., Baverstock et al. 1981; Sarich 1985; Christopher et al. 1992; Boursot et al. 1993; Catzeflis et al. 1993; Chevret et al. 1994; Watts and Baverstock 1994; Agulnik and Silver 1996; Planz et al. $\underline{1996}$ ), as well as general reference books (e.g., Carleton 1984; Carleton and Musser 1984).

Martin et al. (2000) analyzed the complete sequences of the mitochondrial cytochrome b gene for 18 European murid rodent species and found that Acomys occupy a closer position to Murinae. Furthermore, Chevret et al. (1994) examined the relationships of Acomys to other rodents with DNA/DNA hybridization data and found a closer relationship of Acomys to Gerbillinae than to Murinae. However, the "Acomyinae" has been considered as a separate family (Dubois et al. 1999). Their results showed that the phylogenetic position of Acomys is still controversial although they share some morphological similarities with the murinae (e.g., Mus).

Degen et al. (1998) constructed Sigmodontinae and Neotominae as a sister group to the hamsters (Cricetinae) and the voles (Arvicolinae). Robinson et al. (1997) reached the same conclusion when they examined the sequences of the nuclear protein-coding gene LCAT for 19 extant species of rodents including at least one representative for each of the four subfamilies. However, Dickerman's (1992) work does not support this result and suggested the possibility of a polytomy of relationship among these four subfamilies. Watts and Baverstock (1995) studied the relationships among 17 genera of Murinae using microcomplement fixation of albumin and found that Otomys are closer to other murinae, which together with Praomys make a sister group with Arvicanthis and Thallomys. This clade of murinae were found to be related to a clade containing the Australian murine and Mus and Rattus. Also, their results showed that Acomys is closer to Murinae than to Gerbillinae. The phylogenetic position of this genus (Acomys) is highly controversial (see above). Our estimate of the phylogenetic position of gerbil species is obtained from Figure 2 of Degen et al. (1998). Sciuridae

A DNA hybridization study (Giboulet et al. 1997) on marmots and ground squirrels and behavioral characteristics of prairie dogs (Blumstein and Armitage 1997) were used in combination with morphological data (Roth $\underline{1996}$ ) to construct the tree for the studied Sciuridae. Recent studies of cranial morphology were used to assess the relationship 
among Sciurus species (Roth and Dishop 1994; Roth 1996). A polytomy has been used for the studied species of Eutamius because no molecular or morphological data were available.

Heteromyidae and Geomyidae

The sister relationship between these two families is well supported by both molecular (Nedbal et al. 1996) and paleontological data. Hafner and Hafner (1983) described the relationships of three subfamilies of Heteromyidae: Perognathinae (Perognathus and Chaetodipus), Dipodomyinae (Dipodomys and Mirodipodops), and Heteromyinae (Liomys and Heteromys). These phylogenetic relationships are supported by both morphological and chromosomal data. The phylogenetic relationships within the Dipodomys genus are derived from Johnson and Selander (1971), who examined protein variation among 11 species of Dipodomys. We also consulted Best (1993) and Baumgardner and Kennedy (1994).

Hystricognathi Rodents including Octodontoidae

Lessa and Cook (1998) examined the sequences of the mitochondrial cytochrome b gene for some genera of Octodontidae, Ctenomys, Octodontomys, Tympanooctomys, and Spalacopus. They found that a sister group relationship exists between Ctenomys and other genera of Octodontidae and that Octodon is closer to Spalacopus than to Tympanoctomys. Their results have been supported by those of Mascheretti et al. (2000), who investigated the nature of the phylogenetic relationship between species of the family Ctenomyidae by analyzing the variations in the mitochondrial cytochrome b sequences. Furthermore, we obtained the phylogeny of Octodontidae species from recent DNA hybridization studies from J. A. W. Kirsch (personal communication). Phylogenetic relationships of the families of South American Hystricognthi rodents were mainly derived from Nedbal et al. (1994).

Phylogenies Used in Our Analysis

Composite phylogeny for all 164 species or populations represented in Appendix A (in standard bracket notation, as output by the program PDTREE). Branch lengths are Pagel's (1992) arbitrary. This tree is in the PDTREE file BEUC_164.PDI. This tree was pruned to create smaller trees corresponding to the species for which kidney mass $(N=$ $104)$ or RMT $(N=141)$ data were available, as shown below.

(((HC: 10,(((DP: 2,(Mn: 1,CZ: 1): 1): 1,((Ap: 1,Dl: 1): 1,(Hh: 1,HH: 1): 1): 1): 6,(((aC: 1,aB: 1): 1,(cL: 1,Cl: 1): 1): 6,(My: 7,(Ce: 6,((O2: 1,Og: 1): 4,((Tb: 1,Om: 1): 3,((oD: 2,(oB: 1,oL: 1): 1): 1,((Af: 1,As: 1): 1,S2: 2): 1): 1): 1): 1): 1): 1): 1): 1): 1,((Ci: 1,Cc: 1): 7,(Cv: 7,(AR: 6,(((Ts: 1,TS: 1): 1,(Es: 1,Em: 1,EA: 1,Ea: 1): 1): 3,(Xi: 4,Fp: 4,((Sp: 2,(Sb: 1,Sl: 1): 1): 1,(Cu: 1,cl: 1): 2): 1): 1,((TH: 1,Th: 1): 1,(Sv: 1,Sc: 1): 1): 3): 1): 1): 1): 3): 8,(((Pc: 1,P2: 1): 7,(DG: 7,((Mp: 5,((Dd: 1,Dm: 1): 3,(Do: 3,(Ds: 2,(DA: 1,DM: 1): 1): 1): 1): 1): 1,((Cf: 2,(CP: 1,Cb: 1): 1): 1,(Pa: 1,Pl: 1): 2): 3): 1): 1): 10.0,(Zh: 17.0,Jj: 17.0,(((((Ne: 1,Ol: 1): 12.0,((((Ax: 1,Al: 1): 2,(Ao: 2,(Aa: 1,aa: 1): 1): 1): 1,CM: 4): 2,(Bl: 5,(Av: 4,(AB: 3,((AA: 1,aA: 1): 1,am: 2): 1): 1): 1): 1): 6,((cc: 2,CL: 2,(Cm: 1,cm: 1): 1): 9,((Ep: 3,((ET: 1,Et: 1): 1,em: 2,Eh: 2,EM: 2): 1): 7,(Sd: 9,(((ar: 1,a2: 1): 3,(AO: 3,((gg: 1,GG: 1): 1,GD: 2): 1): 1): 4,(Ae: 7,lP: 7,(aS: 1,Ab: 1): 6,(PO: 6,(pO: 5,(((Pv: 2,(Px: 1,PX: 1): 1): 1,(pC: 1,pR: 1): 2): 1,(pM: 1,Pd: 1): 3): 1): 1): 1): 1): 1): 1): 1): 1): 1): 1,((Nm: 1,N2: 1): 3,(OT: 3,((P4: 1,P3: 1,PL: 1): 1,Pe: 2): 1): 1): 10.0): 1,(Dg: 5,((Na: 1,OZ: 1): 3,(Cg: 3,(MA: 2,(Me: 1,MP: 1): 1): 1): 1): 1): 10.0,((Mz: 1,mA: 1,Ma: 1): 1,Cr: 2): 13.0): 1,((Gs: 1,G2: 1): 5,(((sc: 3,(Mh: 2,Ms: 2,MT: 2,(Mu: 1,MU: 1): 1,MC: 2): 1): 1,Po: 4): 1,(Gd: 1,G3: 1,Gg: 1): 4): 1): 3,((((RN: 1,Rr: 1): 4,(Hc: 4,(Mg: 3,(NA: 2,(Ph: 1,PD: 1): 1): 1): 1): 1): 1,aM: 6,(M4: 1,Mm: 1,M2: 1,M1: 1): 5): 1,(Tn: 4,AN: 4,(((Oa: 1,Os: 1,Oi: 1,Ou: 1): 1,(pL: 1,Pb:1): 1): 1,PC: 3): 1): 3): 1,((A5: 1,A4: 1,A3: 1,A2: 1,Ac: 1): 1,aR: 2): 6): 1): 7): 1): 1): 1): 0;

Phylogeny used for analysis of 104 rodent species or populations for kidney mass in standard bracket notation (as output by the program PDTREE). Branch lengths are Pagel's (1992) arbitrary. See Appendix A for species codes. This tree is in the PDTREE file BEK104L.PDI, which includes $\log _{10}$ body mass $(\mathrm{kg})$ as the first trait and $\log _{10}$ kidney mass (g) as the second trait.

((((Mn: 1,CZ: 1): 2,((Ap: 1,Dl: 1): 1,HH: 2): 1): 3,(((aC: 1,aB: 1): 1,cL: 2): 3,(Og: 4,((oD: 2,(oB: 1,oL: 1): 1): 1,((Af: 1,As: 1): 1,S2: 2): 1): 1): 1): 1): 1,(Cv: 5,(TS: 4,(Xi: 3,Fp: 3,((Sp: 1,Sb: 1): 1,(Cu: 1,cl: 1): 1): 1): 1,(Th: 1,Sv: 1): 3): 1): 2): 10,((P2: 4,((Dm: 1,DM: 1): 2,((CP: 1,Cb: 1): 1,Pa: 2): 1): 1): 12,(Zh: 15,Jj: 15,((((Ne: 1,Ol: 1): 10,((((Ax: 1,Al: 1): 2,(Ao: 2,(Aa: 1,aa: 1): 1): 1): 1,CM: 4): 1,(Bl: 4,(Av: 3,(AB: 2,(AA: 1,aA: 1): 1): 1): 1): 1): 5,((cC: 1,CL: 1,cm: 1): 8,((Ep: 2,(ET: 1,Eh: 1,EM: 1): 1): 6,((a2: 2,(GG: 1,GD: 1): 1): 5,(Ae: 6,lP: 6,(aS: 1,Ab: 1): 5,(PO: 5,(pO: 4,(((Pv: 1,PX: 1): 1,(pC: 1,pR: 1): 1): 1,(pM: 1,Pd: 1): 2): 1): 1): 1): 1): 1): 1): 1): 1): 1,(OT: 3,((P4: 1,P3:1): 1,Pe: 2): 1): 9): 1,(Dg: 3,(OZ: 2,(MA: 1,MP: 1): 1): 1): 10,((Mz: 1,mA: 1): 1,Cr: 2): 11): 1,(((sc: 2,(Ms: 1,MT: 1,Mu: 1,MC: 1): 1): 1,(Gd: 1,G3: 1,Gg: 1): 2): 4,((((RN: 1,NA: 1): 1,aM: 2,(M4: 1,M2: 1,M1: 1): 1): 3,(AN: 4,(((Oa: 1,Os: 1,Oi: 1,Ou: 1): 1,(pL: 1,Pb: 1): 1): 1,PC: 3): 1): 1): 1,((A5: 1,A4: 1): 1,aR: 2): 4): 1): 7): 1): 1): 1): 0;

Phylogeny used for analysis of 141 rodent species or populations for relative medullary thickness (RMT) in standard bracket notation (as output by the program PDTREE). Branch lengths are Pagel's (1992) arbitrary. See Appendix A for species codes. This tree is in the PDTREE file BER141L.PDI, which includes $\log _{10}$ body mass $(\mathrm{kg})$ as the first trait and $\log _{10}$ Relative Medullary Thickness as the second trait. 
(((HC: 10,(((DP: 1,Mn: 1): 1,(Dl: 1,Hh: 1): 1): 7,(((aC: 1,aB: 1): 1,(cL: 1,Cl: 1): 1): 6,(My: 7,(Ce: 6,((O2: 1,Og: 1): 4,((Tb: 1,Om: 1): 3,((oD: 2,(oB: 1,oL:1): 1): 1,((Af: 1,As: 1): 1,S2: 2): 1): 1): 1): 1): 1): 1): 1): 1): 1,((Ci: 1,Cc: 1): 5,(AR: 5,((Ts: 2,(Es: 1,Em: 1,EA: 1,Ea: 1): 1): 2,(Xi: 3,Fp: 3,((Sb: 1,Sl: 1): 1,(Cu: 1,cl: 1): 1): 1): 1,(TH: 2,(Sv: 1,Sc: 1): 1): 2): 1): 1): 5): 8,((Pc: 8,(DG: 7,((Mp: 5,((Dd: 1,Dm: 1): 3,(Do: 3,(Ds: 2,(DA: 1,DM: 1): 1): 1): 1): 1): 1,((Cf: 1,CP: 1): 1,Pl: 2): 4): 1): 1): 10,(Jj: 17,(((((Ne: 1,Ol: 1): 12,((((Ax: 1,Al: 1): 2,(Ao: 2,(Aa: 1,aa: 1): 1): 1): 1,CM: 4): 2,(Bl: 5,(Av: 4,(AB: 3,((AA: 1,aA: 1): 1,am: 2): 1): 1): 1): 1): 6,((cc: 2,CL: 2,(Cm: 1,cm: 1): 1): 9,((Ep: 3,((ET: 1,Et: 1): 1,em: 2,Eh: 2,EM: 2): 1): 7,(Sd: 9,(((ar: 1,a2: 1): 3,(AO: 3,((gg: 1,GG: 1): 1,GD: 2): 1): 1): 4,(Ae: 7,lP: 7,(aS: 1,Ab: 1): 6,(PO: 6,(pO: 5,(((Pv: 2,(Px: 1,PX:1): 1): 1,(pC: 1,pR:1): 2): 1,(pM: 1,Pd: 1): 3): 1): 1): 1): 1): 1): 1): 1): 1): 1): 1,((Nm: 1,N2: 1): 1,(P4: 1,P3: 1,PL: 1): 1): 12): 1,(Na: 3,(Cg: 2,(MA: 1,Me: 1): 1): 1): 12,((mA: 1,Ma: 1): 1,Cr: 2): 13): 1,((Gs: 1,G2: 1): 4,(((sc: 2,(Mh: 1,MT: 1,MU: 1,MC: 1): 1): 1,Po: 3): 1,(Gd: 1,G3: 1,Gg: 1): 3): 1): 4,((((RN: 1,Rr: 1): 4,(Hc: 4,(Mg: 3,(NA: 2,(Ph: 1,PD: 1): 1): 1): 1): 1): 1,aM: 6,(M4: 1,Mm: 1): 5): 1,(Tn: 3,((Oa: 1,Os: 1,Oi: 1,Ou: 1): 1,(pL: 1,Pb: 1): 1): 1): 4): 1,((A5: 1,A4: 1,A3: 1,A2: 1,Ac: 1): 1,aR: 2): 6): 1): 7): 1): 1): 1): 0; Other Works Consulted Braun J.K. 1993. Systematic relationships of the tribe Phyllotini (Muridae: Sigmodontinae) of South America. Special Publication Oklahoma Museum of Natural History, Norman, Oklahoma.

Carrasco M.A. 2000. Species discrimination and morphological relationships of kangaroo rats (Dipodomys) based on their dentition. J Mammal 81:107122.

Flynn L.J. 1994. Paleontology: roots of rodent radiation. Nature 370:9798.

Furano A.V., B.E. Hayward, and P. Chevret. 1994. Amplification of the ancient Murine lx family of long interspersed repeated DNA occurred during the murine radiation. J Mol Evol 38:1827.

Glanz W.E. and S. Anderson. 1990. Notes on Bolivian mammals: a new species of Abrocoma (Rodentia) and relationships of the Abrocomidae. Am Mus Novit 2991:132.

Lopez-Martinez N., J. Michaux, and R. Hutterer. 1998. The skull of Stephoanomys and a review of Malpaisomys relationships (Rodentia: Muridae): taxonomic incongruence in Murids. J Mamm Evol 5:185212.

Matthee C.A. and T.J. Robinson. 1997. Molecular phylogeny of the springhare, Pedetes capensis, based on mitochondrial DNA sequences. Mol Biol Evol 14:2029.

Michael R.J. 1987. Comparative myology and phylogenetic systematics of Heteromyidae (Mammalia, Rodentia). Diss Abstr Int 49:2577.

Serdobova I.M. and D. Kramerov. 1998. Short retroposons of the B2 superfamily: evolution and application for the study of rodents' phylogeny. J Mol Evol 46:202214.

Smith M.F. and J.L. Patton. 1993. The diversification of South American murid rodents: evidence from mitochondrial DNA sequence data for the akodontine tribe. Biol J Linn Soc 50:149177.

Stein B.R. 1990. Limb myology and phylogenetic relationships in the superfamily Dipodoidae (birch mice, jumping mice and jerboas). Z Zool Syst Evolutionsforsch 28:299314.

Thomas M. 1993. Early rodents incisor enamel evolution: phylogentic implications. J Mamm Evol 1:227254.

Thomas R.T. 1994. What is a guinea pig? Trends Ecol Evol 9:159160.

Tong Y.S. and M.R. Dawson. 1995. Early Eocene rodents (Mammalia) from Shandong Province, Peoples Republic of China. Ann Carnegie Mus 64:5163.

\section{Literature Cited in Appendix B}

- Agulnik S. and L.M. Silver. 1996. The Cairo spiny mouse Acomys cahirinus shows a strong affinity to the Mongolian gerbil Meriones unguiculatus. Mol Biol Evol 13:36. First citation in article | PubMed

- Baumgardner G.D. and M.L. Kennedy. 1994. Patterns of interspecific morphometric variation in kangaroo rats (genus Dipodomys). J Mammal 75:203211. First citation in article

- Baverstock P.R., C.H. Watts, M. Adams, and S.R. Cole. 1981. Genetical relationships among Australian rodents (Muridae). Aust J Zool 29:189303. First citation in article

- Best T.L. 1993. Patterns of morphologic and morphometric variation in heteromyid rodents. Pp. 197235 in H.H. Genoways and J.H. Brown, eds. Biology of the Heteromyidae. American Society of Mammalogists, Stillwater, Okla. First citation in article

- $\quad$ Blumstein D.T. and K.B. Armitage. 1997. Does sociality drive the evolution of communicative complexity? a comparative test with ground-dwelling Sciurid alarm calls. Am Nat 150:179200. First citation in article

- Boursot P., J.C. Auffray, J. Britton-Davidian, and F. Bonhomme. 1993. The evolution of house mice. Annu Rev Ecol Syst 24:119152. First citation in article | CrossRef 
- Cao Y., J. Adachi, T.A. Yano, and M. Hasegawa. 1994. Phylogenetic place of guinea-pigs: no support of the rodent-polyphyly hypothesis from maximum-likelihood analyses of multiple protein sequences. Mol Biol Evol 11:593604. First citation in article | PubMed

- Carleton M. 1984. Introduction to rodents. Pp. 255265 in S. Anderson and J.K. Jones, Jr., eds. Orders and Families of Recent Mammals of the World. Wiley, New York. First citation in article

- $\quad$ Carleton M.D. and G.G. Musser. 1984. Muroid rodents. Pp. 289379 in S. Anderson and J.K. Jones, Jr., eds. Orders and Families of Recent Mammals of the World. Wiley, New York. First citation in article

- Catzeflis F.M., J.P. Aguilar, and J.J. Jaeger. 1993. Muroid rodents: phylogeny and evolution. Trends Ecol Evol 7:122126. First citation in article | CrossRef

- $\quad$ Chevret P., L. Granjon, J.M. Duplantier, C. Denys, and F. Catzeflis. 1994. Molecular phylogeny of the Praomys complex (Rodentia: Murinae): a study based on DNA/DNA hybridization experiments. Zool J Linn Soc 112:425442. First citation in article | CrossRef

- $\quad$ Christopher H., S. Watts, P.R. Baverstock, J. Birrell, and M. Krieg. 1992. Phylogeny of the Australian rodents (Muridae): a molecular approach using microcomplement fixation of albumin. Aust J Zool 40:8190. First citation in article

- $\quad$ Czelusniak J., M. Goodman, B.F. Koop, D.A. Tagle, J. Shoshani, G. Braunitzer, T.K. Kleinschmidt, W.W. De Jong, and G. Matsuda. 1990. Perspective from amino acid and nucleotide sequences on cladistic relationships among higher taxa of Eutheria. Pp. 545572 in H.H. Genoways, ed. Current Mammalogy. Vol. 2. Plenum, New York. First citation in article

- Degen A.A., M. Kam, I. Khokhlova, W. Krasnov, and T. Barraclough. 1998. Average daily metabolic rate of rodents: habitat and dietary comparisons. Funct Ecol 12:6373. First citation in article | CrossRef

- D'Erchia A.M., C. Gissi, G. Pesole, C. Saccone, and U. Arnason. 1996. The guinea-pig is not a rodent. Nature 381:597600. First citation in article | PubMed | CrossRef

- $\quad$ Dickerman A.W. 1992. Molecular Systematics of Some New World Muroid Rodents. PhD diss. University of WisconsinMadison. First citation in article

- $\quad$ Dubois J.Y., F.M. Catzeflis, and J.J. Beintema. 1999. The phylogentic position of "Acomyinae" (Rodentia, Mammalia) as sister group of a Murinae and Gerbillinae clade: evidence from the molecular ribonuclease gene. Mol Phylogenet Evol 13:181192. First citation in article | PubMed | CrossRef

- Giboulet O., P. Chevret, and R. Ramousse. 1997. DNA-DNA hybridization evidence for the recent origin of marmots and ground squirrels (Rodentia: Sciuridae). J Mamm Evol 4:271282. First citation in article | CrossRef

- $\quad$ Graur D.W.A. and W.H. Li. 1991. Is the guinea-pig a rodent? Nature 351:649652. First citation in article | PubMed | CrossRef

- Hafner J.C. and M.S. Hafner. 1983. Evolutionary relatioships of heteromyid rodents. Great Basin Nat Mem 7:329. First citation in article

- Hasegawa M., Y. Cao, T. Adachi, and T. Yano. 1992. Rodent polyphyly. Nature 355:595. First citation in $\underline{\text { article }}$

- Huchon D., F.M. Catzeflis, and E.J. Douzery. 1999. Molecular evolution of the nuclear von Willebrand Factor gene in mammals and the phylogeny of rodents. Mol Biol Evol 16:577589. First citation in article | PubMed

- . 2000. Variance of molecular datings, evolution of rodents and the phylogenetic affinities between Ctenodactylidae and Hystricognathi. Proc R Soc Lond B Biol Sci 267:393402. First citation in article | PubMed | CrossRef

- Johnson W.E. and R. Selander. 1971. Protein variation and systematics in kangaroo rats (genus Dipodomys). Syst Zool 20:377405. First citation in article

- $\quad$ Lessa E.P. and J.A. Cook. 1998. The molecular phylogentics of tuco-tucos (genus Ctenomys, Rodentia: Octodontidae) suggests an early burst of speciation. Mol Phylogenet Evol 9:8899. First citation in article | PubMed | CrossRef

- $\quad$ Luckett W.P. and J.-L. Hartenberger, eds. 1985. Evolutionary Relationships among Rodents. Plenum, New York. First citation in article

- . 1993. Monophyly or polyphyly of the order Rodentia: possible conflict between morphological and molecular interpretations. J Mamm Evol 1:127147. First citation in article 
- Martin Y., G. Gerlach, C. Schlotterer, and A. Meyer. 2000. Molecular phylogeny of European muroid rodents based on complete cytochrome b sequences. Mol Phylogenet Evol 6:3747. First citation in article | CrossRef

- $\quad$ Mascheretti S., P.M. Mirol, M.D. Gimenez, C. Bidau, J.R. Contreras, and J.B. Searle. 2000. Phylogenetics of the speciose and chromosomally variable rodent genus Ctenomys (Ctenomyidae, Octodontoidea), based on mitochondrial cytochrome b sequences. Biol J Linn Soc 70:361376. First citation in article | CrossRef

- $\quad$ Nedbal M.A., M.W. Allard, and R.L. Honeycutt. 1994. Molecular systematics of hystricognath rodents: evidence from the mitochondrial 12S rRNA gene. Mol Phylogenet Evol 3:206220. First citation in article | PubMed | CrossRef

- $\quad$ Nedbal M.A., R.L. Honeycutt, and D.A. Schlitter. 1996. Higher level systematics of rodents (Mammalia, Rodentia): evidence from the mitochondrial 12S gene. J Mamm Evol 3:201237. First citation in article

- $\quad$ Planz J.V., E.G. Zimmerman, T.A. Spradling, and D.R. Akins. 1996. Molecular phylogeny of the Neotoma floridana species group. J Mammal 77:519535. First citation in article

- $\quad$ Robinson M., F. Catzeflis, L. Briolay, and D. Mouchiroud. 1997. Molecular phylogeny of rodents, with special emphasis on murids: evidence from nuclear gene LCAT. Mol Phylogenet Evol 8:423434. First

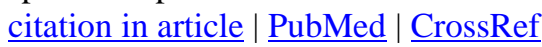

- $\quad$ Roth V.L. 1996. Cranial integration in the Sciuridae. Am Zool 36:1423. First citation in article

- $\quad$ Roth V.L. and M.K. Dishop. 1994. Evolutionary relationships among the Sciuridae: analysis of cranial characters in tree, ground, and flying squirrels. J Morphol 220:388407. First citation in article

- $\quad$ Sarich V. 1985. Rodent macromolecular systematics. Pp. 423452 in W.P. Luckett and J.-L. Hartenberger, eds. Evolutionary Relationships among Rodents: A Multidisciplinary Analysis. Springer, Berlin. First citation in article

- Shoshani J. 1986. Mammalian phylogeny: comparison of morphological and molecular results. Mol Biol Evol 3:222242. First citation in article | PubMed

- Watts C.H. and P.R. Baverstock. 1994. Evolution in some South-East Asian Murinae (Rodentia), as assessed by microcomplement fixation of albumin, and their relationship to Australian murines. Aust J Zool 42:711 722. First citation in article

- . 1995. Evolution in some African Murinae (Rodentia) assessed by microcomplement fixation of albumin. J Afr Zool 109:423433. First citation in article

\section{Literature Cited}

- $\quad$ Abrahams S., L. Greenwald, and D. Stetson. 1991. Contribution of renal medullary mitochondrial density to urine concentrating ability in mammals. Am J Physiol 261:R719R726. First citation in article | PubMed

- Al-kahtani M.A. 2003. Evolutionary and Phenotypic Plasticity of Mammalian Kidney: Using the Laboratory House Mouse as a Model. PhD diss. University of WisconsinMadison. First citation in article

- $\quad$ Altschuler E.M., R.B. Nagle, D.J. Braun. S.L. Lindstedt, and P.H. Krutzsch. 1979. Morphological study of the desert heteromyid kidney with emphasis on the genus Perognathus. Anat Rec 194:461468. First citation

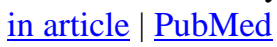

- Bakko E.B. 1975. Field water balance performance in prairie dogs (Sciurus carolinensis) and red squirrels (Tamiasciurus hudsonicus). Comp Biochem Physiol 51A:759768. First citation in article

- Bankir L. and C. de Rouffignac. 1985. Urinary concentrating ability: insights from comparative anatomy. Am J Physiol 249:R643R666. First citation in article | PubMed

- $\quad$ Bankir L., C. Fischer, S. Fischer, K. Jukkala, H.C. Specht, and W. Kriz. 1988. Adaptation of the rat kidney to altered water intake and urine concentration. Pflueg Arch 412:4253. First citation in article

- Baudinette R.V. 1974. The physiology of chronic water deprivation in the California ground squirrel (Spermophilus beecheyi): relevance to natural populations. J Zool (Lond) 173:159171. First citation in article

- $\quad$ Berry R.J. and M.E. Jakobson. 1975. Adaptation and adaptability in wild-living house mice (Mus musculus). J Zool (Lond) 176:391402. First citation in article

- $\quad$ Beuchat C.A. 1990. Metabolism and the scaling of urine concentrating ability in mammals: resolution of a paradox? J Theor Biol 143:113122. First citation in article | PubMed

- $\quad$. 1991. Body size, medullary thickness, and urine concentrating ability in mammals. Am J Physiol 258:R298 R308. First citation in article 
- $\quad$. 1993. The scaling of concentrating ability in mammals. Pp. 259279 in J.A. Brown, R.J. Balment, and J.C. Rankin, eds. New Insights in Vertebrate Kidney Function. Cambridge University Press, Cambridge. First citation in article

- $\quad$. 1996. Structure and concentrating ability of the mammalian kidney: correlations with habitat. Am J Physiol 271:R157R179. First citation in article | PubMed

- $\quad$ Blake B.H. 1977. The effects of kidney structure and the annual cycle on water requirements in goldenmantled ground squirrels and chipmunks. Comp Biochem Physiol 58A:413419. First citation in article

- $\quad$ Blomberg S.P. and T. Garland, Jr. 2002. Tempo and mode in evolution: phylogenetic inertia, adaptation and comparative methods. J Evol Biol 15:899910. First citation in article | CrossRef

- Blomberg S.P., T. Garland, Jr., and A.R. Ives. 2003. Testing for phylogenetic signal in comparative data: behavioral traits are more labile. Evolution 57:717745. First citation in article | PubMed

- $\quad$ Borut A. and A. Shkolnik. 1974. Physiological adaptations to the desert environment. Pp. 185229 in D. Robertshaw, ed. Environmental Physiology. Vol. 7. University Park Press, Baltimore. First citation in article

- Braun J.E. 1998. Comparative renal function in reptiles, birds, and mammals. Pp. 6271. Seminars in Avian and Exotic Pet Medicine. Vol. 7. Saunders, Philadelphia. First citation in article

- Breyen L.J., W.G. Bradley, and M.K. Yousef. 1973. Physiological and ecological studies on the chiseltoothed kangaroo rat, Dipodomys microps. Comp Biochem Physiol 44A:543555. First citation in article

- Brosh A. 1971. Correlation between Kidney Structure and Urine Concentration Ability. Undergraduate thesis. Oranim College, Tivon, Israel. First citation in article

- Brownfield M.S. and B.A. Wunder. 1976. Relative medullary area: a new structural index for estimating urinary concentrating capacity of mammals. Comp Biochem Physiol 55A:6975. First citation in article

- Burns T.W. 1956. Endocrine factors in the water metabolism of the desert mammal. Gerbillus gerbillus. Endocrinology 58:243254. First citation in article | PubMed

- $\quad$ Butynski T.M. 1979. Body and organ growth of the springhare (Pedetes capensis). Acta Theriol 24:431448. First citation in article

- $\quad$ Calder W.A. and E.L. Braun. 1983. Scaling of osmotic regulation in mammals and birds. Am J Physiol 244:R601R606. First citation in article | PubMed

- Carpenter R.E. 1966. A comparison of thermoregulation and water metabolism in the kangaroo rats Dipodomys agilis and Dipodomys merriami. Univ Calif Publ Zool 78:136. First citation in article

- Collins B.G. 1978. Water metabolism and the distribution of two species of Australian murids, Rattus rattus and Rattus villosissimus. Comp Biochem Physiol 61A:647651. First citation in article

- Cook R.D. and S. Weisberg. 1999. Applied Regression Including Computing and Graphics. Wiley, New York. First citation in article

- Cortes A., M. Rosenmann, and C. Baez. 1990. Función del riñón y del pasaje nasal en la conservación de agua corporal en roedores simpátridos de Chile Central. Rev Chil Hist Nat 63:279291. First citation in article

- $\quad$ Cruz-Neto A.P., T. Garland, Jr., and A.S. Abe. 2001. Diet, phylogeny, and basal metabolic rate in phyllostomid bats. Zoology 104:4958. First citation in article

- $\quad$ Dantzler W.H. and E.J. Braun. 1980. Comparative nephron function in reptiles, birds, and mammals. Am J Physiol 239:R197R213. First citation in article | PubMed

- Deavers D.R. and J.W. Hudson. 1979. Water metabolism and estimated field water budgets in two rodents (Clethrionomys gapperi and Peromyscus leucopus) and an insectivore (Blarina bervicauda) inhabiting the same mesic environment. Physiol Zool 52:137152. First citation in article

- $\quad$ de Rouffignac C., L. Bankir, and N. Roinel. 1981. Renal function and concentrating ability in a desert rodent: the gundi (Ctenodactylus vali). Pflueg Arch 239:138144. First citation in article

- $\quad$ Diaz G.B. and R.A. Ojeda. 1999. Kidney structure and allometry of Argentine desert rodents. J Arid Environ 41:453461. First citation in article | CrossRef

- Dolph C.I., H.A. Braun, and E.W. Pfeiffer. 1962. The effect of vasopressin upon urine concentration in Aplodontia rufa (Sewellel) and the rabbit. Physiol Zool 35:263269. First citation in article

- $\quad$ Downs C.T. and M.R. Perrin. 1991. Urinary concentrating ability of four Gerbillurus species of southern African arid regions. J Arid Environ 20:7181. First citation in article

- $\quad$ Edwards B.A., K. Donaldson, and A.P. Simpson. 1983. Water balance and protein intake in the Mongolian gerbil (Meriones uniguiculatus). Comp Biochem Physiol 76A:807815. First citation in article 
- $\quad$ Eisenberg J.F. 1981. The Mammalian Radiations. University of Chicago Press, Chicago. First citation in $\underline{\text { article }}$

- $\quad$ Felsenstein J. 1985. Phylogenies and the comparative method. Am Nat 125:115. First citation in article

- $\quad$ Folk G.E., Jr. 1974. Textbook of Environmental Physiology. 2d ed. Lea \& Febiger, Philadelphia. First citation in article

- $\quad$ Frean J., C.T. Downs, and B.G. Lovegrove. 1998. Osmoregulatory capacity of an arboreal rodent Thallomys nigricauda. J Arid Environ 40:97107. First citation in article $\mid \underline{\text { CrossRef }}$

- $\quad$ Freckleton R.P., P.H. Harvey, and M. Pagel. 2002. Phylogenetic analysis and comparative data: a test and review of evidence. Am Nat 160:712726. First citation in article

- Garland T., Jr. 2001. Phylogenetic comparison and artificial selection: two approaches in evolutionary physiology. Pp. 107132 in R.C. Roach, P.D. Wagner, and P.H. Hackett, eds. Hypoxia: From Genes to the Bedside. Advances in Experimental Biology and Medicine. Vol. 502. Kluwer Academic/Plenum, New York. First citation in article

- $\quad$ Garland T., Jr., and S.C. Adolph. 1991. Physiological differentiation of vertebrate populations. Annu Rev Ecol Syst 22:93228. First citation in article

- $\quad$. 1994. Why not to do two-species comparative studies: limitations on inferring adaptation. Physiol Zool 67:797828. First citation in article

- Garland T., Jr., and R. Díaz-Uriarte. 1999. Polytomies and phylogenetically independent contrasts: an examination of the bounded degrees of freedom approach. Syst Biol 48:547558. First citation in article | PubMed | CrossRef

- Garland T., Jr., A.W. Dickerman, C. Janis, and J.A. Jones. 1993. Phylogenetic analysis of covariance by computer simulation. Syst Biol 42:265292. First citation in article

- $\quad$ Garland T., Jr., P.H. Harvey, and A.R. Ives. 1992. Procedures for the analysis of comparative data using phylogenetically independent contrasts. Syst Biol 41:1832. First citation in article

- Garland T., Jr., and A.R. Ives. 2000. Using the past to predict the present: confidence intervals for regression equations in phylogenetic comparative methods. Am Nat 155:346364. First citation in article | Full Text | PubMed

- $\quad$ Garland T., Jr., P.E. Midford, and A.P. Ives. 1999. An introduction to phylogenetically based statistical methods, with a new method for confidence intervals on ancestral values. Am Zool 39:374388. First citation in article

- Geluso K.N. 1978. Urine concentrating ability and renal structure of insectivorous bats. J Mammal 59:312 323. First citation in article $\mid$ PubMed

- Gottschalk W.C. 1987. History of the urinary concentrating mechanism. Kidney Int 31:507511. First citation in article $\mid \underline{\text { PubMed }}$

- $\quad$ Goyal S.P., P.K. Ghosh, T.O. Sasidharan, and P. Chand. 1988. Body water relations in two species of gerbil (Tatera indica indica and Meriones hurrianae) of the Indian desert. J Comp Physiol 158B:127134. First citation in article

- Grafen A. 1989. The phylogenetic regression. Biol Sci 326:119157. First citation in article

- Greegor D.H., Jr. 1975. Renal capabilities of an Argentine desert armadillo. J Mammal 56:626632. First citation in article

- $\quad$ Greenwald L. 1989. The significance of renal relative medullary thickness. Physiol Zool 62:10051014. First citation in article

- $\quad$ Greenwald L. and D. Stetson. 1988. Urine concentration and the length of the renal papilla. News Physiol Sci 3:4649. First citation in article

- Haines H. and B. Schmidt-Nielsen. 1977. Kidney function in spiny mice (Acomys cahirinus) acclimated to water restriction. Bull Mt Desert Isl Biol Lab 17:9495. First citation in article

- Harlow H.J. and E.L. Braun. 1995. Kidney structure and function of obligate and facultative hibernators: the white-tailed prairie dog (Cynomys leucurus) and the black-tailed prairie dog (Cynomys ludovicianus). $\mathrm{J}$ Comp Physiol 165B:320328. First citation in article

- Heisinger J.F. and S. Breitenbach. 1969. Renal structural characteristics as indexes of renal adaptation for water conservation in the genus Sylvilagus. Physiol Zool 42:160172. First citation in article

- Heisinger J.F., T.S. King, H.W. Halling, and B.L. Fields. 1973. Renal adaptation to macro- and microhabitats in the family Cricetidae. Comp Biochem Physiol 44A:767774. First citation in article 
- Heller C.H. and T. Poulson. 1972. Altitudinal zonation of chipmunks (Eutamias): adaptations to aridity and high temperature. Am Midl Nat 87:296313. First citation in article

- Hewitt S. 1981. Plasticity of renal function in the Australian desert rodent Notomys alexis. Comp Biochem Physiol 69A:297304. First citation in article

- Hickman G.C. and L.N. Brown. 1973. Pattern and rate of mound production in the southeastern pocket gopher (Geomys pinetis). J Mammal 54:971975. First citation in article

- Huey R.B. and A.F. Bennett. 1990. Physiological adjustments to fluctuating thermal environments: an ecological and evolutionary perspective. Pp. 3759 in R. Morimoto and A. Tissieres, eds. Stress Proteins in Biology and Medicine. Cold Spring Harbor Laboratory Press, Cold Spring, N.Y. First citation in article

- Hutcheon J.M., J.A.W. Kirsch, and T. Garland, Jr. 2002. A comparative analysis of brain size in relation to foraging ecology and phylogeny in the Chiroptera. Brain Behav Evol 60:165180. First citation in article | PubMed | CrossRef

- $\quad$ Khalil F. and J. Tawfic. 1963. Some observations on the kidney of the desert Jaculus jaculus and Gerbillus gerbillus and their possible bearing on the water economy of these animals. J Exp Zool 154:259271. First citation in article | PubMed

- $\quad$ Kelt D.A., R.E. Palma, M.H. Gallardo, and J.A. Cook. 1991. Chromosomal multiformity in Eligmodontia (Muridae, Sigmodontinae), and verification of the status of Eligmodontia morgani. Z Säugetierkd 56:352 358. First citation in article

- Kramer A.W. 1964. Body and organ weights and linear measurements of the adult Mongolian gerbil. Anat Rec 150:343348. First citation in article | PubMed

- $\quad$ Lawler R.M. and K.N. Geluso. 1986. Renal structure and body size in heteromyid rodents. J Mammal 67:367 372. First citation in article

- $\quad$ Layne J.N. 1954. The biology of the red squirrel, Tamiasciurus hudsonicus loquax (Bangs), in central New York. Ecol Monogr 24:227267. First citation in article

- Leroi A.M., M.R. Rose, and G.V. Lauder. 1994. What does the comparative method reveal about adaptation? Am Nat 143:381402. First citation in article

- $\quad$ MacMillen R.E., R.V. Baudinette, and A.K. Lee. 1972. Water economy and energy metabolism of the sand inland mouse Leggadina hermannsburgensis. J Mammal 53:529539. First citation in article

- MacMillen R.E. and T. Garland, Jr. 1989. Adaptive physiology. Pp. 143168 in J.N. Lane and G.L. Kirkland, Jr., eds. Advances in the Study of Peromyscus (Rodentia). Texas Tech University Press, Lubbock. First citation in article

- $\quad$ MacMillen R.E. and D.S. Hinds. 1983. Water regulatory efficiency in heteromyid rodents: a model and its application. Ecology 64:152164. First citation in article

- $\quad$ MacMillen R.E. and A.K. Lee. 1967. Australian desert mice: independence of exogenous water. Science 158:383385. First citation in article $\mid \underline{\text { PubMed }}$

- $\quad$. 1969. Water metabolism of Australian hopping mice. Comp Biochem Physiol 28:493514. First citation in article | CrossRef

- $\quad$ Mares M.A., R.A. Ojeda, and R .M. Barquez. 1989. Guide to the Mammals of Salta Province, Argentina. University of Oklahoma Press, Norman. First citation in article

- $\quad$ Mares M.A., R.A. Ojeda, J.K. Braun, and R.M. Barquez. 1997. Systematics, distribution, and ecology of the mammals of Catamarca Province, Argentina. Pp. 89154 in T.L. Yates, W.L. Gannon, and D.E. Wilson, eds. Life among the Muses: Papers in Honor of James S. Findley. Museum of Southwestern Biology, University of New Mexico, Albuquerque. First citation in article

- Marsh A.C., G. Louw, and H.H. Berry. 1978. Aspects of renal physiology nutrition and thermoregulation in the ground squirrel Xerus inauris. Madoqua 2:129135. First citation in article

- Munkacsi I. and M. Palkovits. 1965. Volumetric analysis of glomerular size in kidneys of mammals living in desert, semidesert or water-rich environment in the Sudan. Circ Res 17:303311. First citation in article | PubMed

- $\quad$ 1977. Measurements on the kidneys and vasa recta of various mammals in relation to urine concentrating capacity. Acta Anat 98:456468. First citation in article

- Musser G.M. and M.D. Carleton. 1993. Family Muridae. Pp. 501756 in D.E. Wilson and D.M. Reeder, eds. Mammal Species of the World: A Taxonomic and Geographic Reference. 2d ed. Smithsonian Institution, Washington, D.C. First citation in article 
- $\quad$ Nungesser W.C. and E.W. Pfeiffer. 1965. Water balance and maximum concentrating capacity in the primitive rodent, Aplodontia rufa. Comp Biochem Physiol 14B:289297. First citation in article

- $\quad$ Ojeda R.A., C.E. Borghi, G.B. Diaz, S.M. Giannoni, M.A. Mares, and J.K. Braun. 1999. Evolutionary convergence of the highly adapted desert rodent Tympanoctomys barrerae (Octodontidae). J Arid Environ 41:443452. First citation in article | CrossRef

- Oswald C. 1998. Geographic variation and plasticity in renal function in the white-footed mouse, Peromyscus leucopus. J Mammal 79:11031110. First citation in article

- $\quad$ Pagel M.D. 1992. A method for the analysis of comparative data. J Theor Biol 156:431442. First citation in $\underline{\text { article }}$

- Pfeiffer E.W. 1970. Ecological and anatomical factors affecting the gradient of urea and non-urea solutes in mammalian kidneys. Pp. 358365 in B. Schmidt-Nielsen and D.W.S. Kerr, eds. Urea and the Kidney. Excerpta Medica Foundation, Amsterdam. First citation in article

- $\quad$ Pillay N., K. Willan, and P.J. Taylor. 1994. Comparative renal morphology of some southern African otomyine rodents. Acta Theriol 39:3748. First citation in article

- $\quad$ Price M.V. and W.S. Longland. 1989. Use of artificial seed patches by heteromyid rodents. J Mammal 70:316322. First citation in article

- Purohit K.G. 1974a. Observation on histomorphology of kidneys and urine osmolarities in some Australian desert rodents. Zool Anz 193:221227. First citation in article

- $\quad .1974 b$. Observations on the role of kidney in survival of Tammar wallaby (Macropus eugenii, Marsupialia) on sea water. Z Angew Zool 61:495506. First citation in article

- $\quad$. 1975. Histomorphology of kidney in the Indian desert gerbil, Meriones hurrianae and ecophysiological appraisal. Z Angew Zool 62:922. First citation in article

- $\quad$ Purohit K.G., C.P. Batra, and B.S. Gaur. 1973. Linear dimensions and relative medullary thickness in kidneys of some small Indian mammals. Indian J Zool 1:9599. First citation in article

- $\quad$ Purohit K.G. and P.K. Ghosh. 1965. The organ : body weight relationships in the northern palm squirrel, Funambulus pennanti (Wroughton). Mammalia 29:3541. First citation in article

- Purvis A. and T. Garland, Jr. 1993. Polytomies in comparative analysis of continuos characters. Syst Biol 42:569573. First citation in article

- $\quad$ Quiring D.P. 1950. Functional Anatomy of the Vertebrates. McGraw-Hill, New York. First citation in article

- $\quad$ Rabhi M., M.V. Ugrumov, O.A. Goncharevskaya, W. Bengelloun, A. Calas, and Y.V. Natochin. 1996. Development of the hypothalamic vasopressin system and nephrons in Meriones shawi during ontogenesis. Anat Embryol 193:281296. First citation in article | PubMed

- $\quad$ Redford K.H. and J.F. Eisenberg. 1992. Mammals of the Neotropics. Vol. 2. The Southern Cone. University of Chicago Press, Chicago. First citation in article

- $\quad$ Reid I.A. and I.R. McDonald. 1968. Renal function in the marsupial, Trichosurus vulpecula. Comp Biochem Physiol 26B:10711079. First citation in article

- $\quad$ Rezende E.L., F. Bozinovic, and T. Garland, Jr. 2004. Climatic adaptation and the evolution of basal and maximum rates of metabolism in rodents. Evolution 58:13611374. First citation in article | PubMed

- Rezende E.L. and T. Garland, Jr. 2003. Comparaciones interespecíficas y métodos estadísticos filogenéticos. Pp. 7998 in F. Bozinovic, ed. Fisiología Ecológica and Evolutiva. Teoría y casos de estudios en animales. Ediciones Universidad Católica de Chile, Santiago. First citation in article

- $\quad$ Rohlf F.J. 2001. Comparative methods for the analysis of continuous variables: geometric interpretations. Evolution 55:21432160. First citation in article | PubMed

- Schmid W.D. 1972. Nocturnalism and variance in ambient vapor pressure of water. Physiol Zool 45:302309. First citation in article

- Schmidt-Nielsen B. and R. O'Dell. 1961. Structure and concentrating mechanism in the mammalian kidney. Am J Physiol 200:11191124. First citation in article | PubMed

- Schmidt-Nielsen B., K. Schmidt-Nielsen, A. Brokaw, and H. Schneiderman. 1948. Water conservation in desert rodents. J Cell Comp Physiol 32:331360. First citation in article

- Schmidt-Nielsen K. 1964. Desert Animals: Physiological Problems of Heat and Water. Oxford University Press, New York. First citation in article

- Shkolnik A.1988. Physiological adaptations to the environment: the Israeli experience. Pp. 487496 in Y. Yom-Tov and E. Tchernov, eds. The Zoogeography of Israel. W. Junk, The Hague. First citation in article 
- Silva M. and J.A. Downing. 1995. CRC Handbook of Mammalian Body Masses. CRC, Boca Raton, Fla. First citation in article

- $\quad$ Spector W.S. 1956. Handbook of Biological Data. Saunders, Philadelphia. First citation in article

- $\quad$ Sperber I. 1944. Studies on the mammalian kidney. Zool Bidr Upps 22:249432. First citation in article

- $\quad$ Spotorno A.E., H. Cofre, G. Manriquez, Y. Vilina, P.A. Marquet, and L.I. Walter. 1998. A new species of Loxodontomys, another phyllotine mammal from the Andes of central Chile. Rev Chil Hist Nat 71:359373. First citation in article

- $\quad$ Spotorno A.E., J. Sufan-Catalan, and L.I. Walker. 1994. Cytogenetics diversity and evolution of Andean species of Eligmodontia (Rodentia, Muridae). Z Säugetierkd 59:299308. First citation in article

- $\quad$ Spotorno A.E., L.I. Walker, S.V. Flores, M. Yevennes, J.C. Marin, and C. Zuleta. 2000. Evolución de los filotinos (Rodentia, Muridae) en los Andes del Sur. Rev Chil Hist Nat 74:151166. First citation in article

- Spotorno A.E., C.A. Zuleta, and A. Cortés. 1990. Evolutionary systematics and heterocrony in Abrothrix species (Rodentia, Cricetidae). Evol Biol 4:3762. First citation in article

- Tieleman B.I., J.B. Williams, and P. Bloomer. 2003. Adaptation of metabolism and evaporative water loss along an aridity gradient. Proc R Soc Lond B Biol Sci 270:207214. First citation in article | PubMed | CrossRef

- Trojan M. 1977. Water balance and renal adaptations in four Palaearctic hamsters. Naturwissenschaften 64:591592. First citation in article | PubMed

- $\quad$ 1979. Comparative investigations on the water budget and the kidney function in the Palaearctic hamsters Cricetus cricetus (Leske, 1779), Mesocricetus auratus (Waterhouse, 1839), Cricetulus griseus (MilneEdwards, 1867) and Phodopus sungorus (Pallas, 1770). Zool Jahrb Abt Allg Zool Physiol Tiere 83:192223. First citation in article

- Vanhooydonck B. and R. Van Damme. 1999. Evolutionary relationships between body shape and habitat use in lacertid lizards. Evol Ecol Res 1:785805. First citation in article

- Weissenberg S. 1977. Comparative Physiology in Two Populations of Common Spiny Mouse (Acomys cahirinus) from Desert and Mediterranean Regions. MSc thesis. Tel Aviv University. (Hebrew with English abstract.) First citation in article

- Weisser F., F.B. Lacy, H. Weber, and R.L. Jamison. 1970. Renal function in the chinchilla. Am J Physiol 219:17061713. First citation in article | PubMed

- Wilson D.E. and D.M. Reeder, eds. 1993. Mammal Species of the World: A Taxonomic and Geographic Reference. 2d ed. Smithsonian Institution, Washington, D.C. First citation in article

- Yaakobi D. and A. Shkolnik. 1974. Structure and concentrating capacity in kidneys of three species of hedgehogs. Am J Physiol 226:948952. First citation in article | PubMed 